\title{
Global multi-year $\mathrm{O}_{3}$-CO correlation patterns from models and TES satellite observations
}

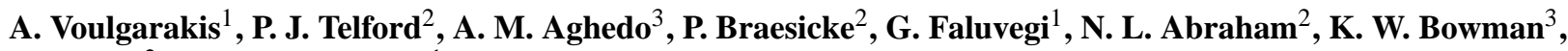 \\ J. A. Pyle ${ }^{2}$, and D. T. Shindell ${ }^{1}$ \\ ${ }^{1}$ NASA Goddard Institute for Space Studies \& Columbia University, Center for Climate Systems Research, New York, USA \\ ${ }^{2}$ NCAS-Climate, Centre for Atmospheric Science, Department of Chemistry, University of Cambridge, UK \\ ${ }^{3}$ Jet Propulsion Laboratory, California Institute of Technology, Pasadena, California, USA
}

Received: 14 December 2010 - Published in Atmos. Chem. Phys. Discuss.: 10 February 2011

Revised: 21 May 2011 - Accepted: 13 June 2011 - Published: 22 June 2011

\begin{abstract}
The correlation between measured tropospheric ozone $\left(\mathrm{O}_{3}\right)$ and carbon monoxide $(\mathrm{CO})$ has been used extensively in tropospheric chemistry studies to explore the photochemical characteristics of different regions and to evaluate the ability of models to capture these characteristics. Here, we present the first study that uses multi-year, global, vertically resolved, simultaneous and collocated $\mathrm{O}_{3}$ and CO satellite (Tropospheric Emission Spectrometer) measurements, to determine this correlation in the middle/lower free troposphere for two different seasons, and to evaluate two chemistry-climate models. We find results that are fairly robust across different years, altitudes and timescales considered, which indicates that the correlation maps presented here could be used in future model evaluations. The highest positive correlations (around 0.8) are found in the northern Pacific during summer, which is a common feature in the observations and the G-PUCCINI model. We make quantitative comparisons between the models using a single-figure metric $(C)$, which we define as the correlation coefficient between the modeled and the observed $\mathrm{O}_{3}$-CO correlations for different regions of the globe. On a global scale, the G-PUCCINI model shows a good performance in the summer $(C=0.71)$ and a satisfactory performance in the winter $(C=0.52)$. It captures midlatitude features very well, especially in the summer, whereas the performance in regions like South America or Central Africa is weaker. The UKCA model $(C=0.46 / 0.15$ for July-August/December-January on a global scale) performs better in certain regions, such as the tropics in winter, and it captures some of the broad characteristics of summer extratropical correlations, but it
\end{abstract}

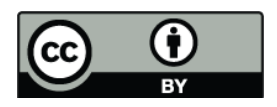

Correspondence to: A. Voulgarakis (avoulgarakis@giss.nasa.gov) systematically underestimates the $\mathrm{O}_{3}-\mathrm{CO}$ correlations over much of the globe. It is noteworthy that the correlations look very different in the two models, even though the ozone distributions are similar. This demonstrates that this technique provides a powerful global constraint for understanding modeled tropospheric chemical processes. We investigated the sources of the correlations by performing a series of sensitivity experiments. In these, the sign of the correlation is, in most cases, insensitive to removing different individual emissions, but its magnitude changes downwind of emission regions when applying such perturbations. Interestingly, we find that the $\mathrm{O}_{3}-\mathrm{CO}$ correlation does not solely reflect the strength of $\mathrm{O}_{3}$ photochemical production, as often assumed by earlier studies, but is more complicated and may reflect a mixture of different processes such as transport.

\section{Introduction}

Tropospheric ozone $\left(\mathrm{O}_{3}\right)$ and carbon monoxide $(\mathrm{CO})$ are well-known pollutants, majorly affecting the oxidizing capacity of the troposphere and exerting a direct $\left(\mathrm{O}_{3}\right)$ and indirect $\left(\mathrm{CO}\right.$ and $\left.\mathrm{O}_{3}\right)$ influence on climate. In addition to being driven by natural and anthropogenic emissions, their concentrations also depend on a wide range of chemical and physical processes that take place in the troposphere (Logan et al., 1981; Lelieveld and Dentener, 2000). CO is a precursor of $\mathrm{O}_{3}$, but the relationship between their abundances is not easily defined, as it also depends on the concentrations of other trace gases and on the meteorological conditions. The stratospheric influence on tropospheric chemistry and the deposition of $\mathrm{O}_{3}$ on the Earth's surface can make this relationship even more complicated.

Published by Copernicus Publications on behalf of the European Geosciences Union. 
In the past, the correlations between $\mathrm{O}_{3}$ and $\mathrm{CO}$ concentrations from observations have been used in order to understand the anthropogenic influence on $\mathrm{O}_{3}$. The most thoroughly studied area has been the northeastern US and the pollution outflow region in the northern Atlantic. There have been studies on this region using surface measurements (Parrish et al., 1993; Chin et al., 1994; Parrish et al., 1998; Cárdenas et al., 1998; Li et al., 2002; Honrath et al., 2004; Mao and Talbot, 2004) and using aircraft measurements (Buhr et al., 1996; Daum et al., 1996; Cooper et al., 2002b,a; Huntrieser et al., 2005). They all showed that $\mathrm{O}_{3}-\mathrm{CO}$ correlations in the summer, when photochemistry is at its peak, are positive and often strong, depending on the weather patterns that prevailed during the measurement period (Cooper et al., 2002a,b).

Since CO is a good indicator for industrial and biomass burning pollution (Logan et al., 1981), a positive correlation with $\mathrm{O}_{3}$ indicates that a region has experienced photochemical $\mathrm{O}_{3}$ production from its precursors (including $\mathrm{CO}$ ). A negative $\mathrm{O}_{3}-\mathrm{CO}$ correlation is found in the northern Atlantic in the winter (Parrish et al., 1998; Cárdenas et al., 1998; Li et al., 2002; Mao and Talbot, 2004) which can indicate that $\mathrm{O}_{3}$ destruction through $\mathrm{NO}_{\mathrm{x}}\left(\mathrm{NO}+\mathrm{NO}_{2}\right)$ titration is favoured when pollution increases. However, in Chin et al. (1994) and Real et al. (2008) it was also discussed that negative correlations can sometimes result from secondary CO production from hydrocarbon oxidation (which leads to $\mathrm{CO}$ being produced but $\mathrm{O}_{3}$ being consumed), instead of photochemical $\mathrm{O}_{3}$ destruction. Similarly, positive $\mathrm{O}_{3}-\mathrm{CO}$ correlations can be explained by $\mathrm{CO}$ destruction, rather than $\mathrm{O}_{3}$ production. However, we expect that these alternative explanations do not apply to the majority of cases. We also need to note that there are cases when the $\mathrm{O}_{3}-\mathrm{CO}$ correlation is driven by factors not affected by chemistry, like when a strong stratospheric intrusion occurs. In such cases, it is expected that the correlation will be negative, since stratospheric air is rich in $\mathrm{O}_{3}$ but poor in $\mathrm{CO}$ (e.g. Parrish et al., 1998).

For another pollution outflow region, the northwestern Pacific, several studies (Jaffe et al., 1996; Kajii et al., 1998; Pochanart et al., 1999; Mauzerall et al., 2000; Tsutsumi and Matsueda, 2000; Kato et al., 2004; Suthawaree et al., 2008; Tanimoto et al., 2008) found that the broad characteristics of the $\mathrm{O}_{3}-\mathrm{CO}$ correlations are similar to those of the northern Atlantic: positive correlations in the summer and negative in the winter, whereas in spring, when stratospheric intrusions are common, correlations are often negative (Hsu et al., 2004). Apart from those well-known pollution outflow regions, other correlation analyses using in-situ measurements have focused on different areas around the globe, including continental Asia and America (Chin et al., 1994; Naja et al., 2003; Gao et al., 2005; Wang et al., 2006, 2008; Ding et al., 2009), Europe (Zahn et al., 2000; Fischer et al., 2003), the eastern Pacific (Nowak et al., 2004; Bertschi and Jaffe, 2005; Swartzendruber et al., 2008), the tropics (Andreae et al., 1994; Harris et al., 1998; Sanhueza et al., 1999;
Chan et al., 2002; Takegawa et al., 2003; Wang et al., 2004; Henne et al., 2008; Ancellet et al., 2009; Shim et al., 2009) and high latitude sites (Jaffe et al., 1998; Harris et al., 2000). These analyses revealed similarities and differences between the various regions, which will not be documented here, but will be referred to later in this manuscript whenever necessary.

Although there have been many studies that examined the important topic of $\mathrm{O}_{3}-\mathrm{CO}$ correlations, their reliance on surface/aircraft observations has left much of the globe unexplored. The aircraft campaigns provided relatively good (though far from complete) spatial coverage, but for limited periods. The satellite observations from the Tropospheric Emissions Spectrometer (TES; Beer et al., 2001) provide a unique opportunity to study the global multi-year $\mathrm{O}_{3}-\mathrm{CO}$ correlation from collocated and simultaneous, vertically resolved tropospheric $\mathrm{O}_{3}$ and $\mathrm{CO}$ data. There have been a few recent studies that have taken advantage of this dataset for this purpose, but they have either focused on particular regions (Zhang et al., 2008; Shim et al., 2009) or examined a limited time-period (Zhang et al., 2006). Here, we expand the scope of Zhang et al. (2006) (who focused on July 2005) to examine the middle/lower free tropospheric $\mathrm{O}_{3}-\mathrm{CO}$ correlation patterns around the globe in two different seasons (Northern Hemisphere summer/winter), using a multi-year (2005-08) dataset. Since the $\mathrm{O}_{3}-\mathrm{CO}$ correlation analysis provides information on whether a model captures $\mathrm{O}_{3}$ levels for the right reasons (Chin et al., 1994), we also employ two different models that we evaluate in terms of their ability to capture the correlation patterns. Furthermore, we perform a sensitivity analysis, in which the effect of different emissions on the correlations is examined.

In Sect. 2 we provide some information about the TES observations and the two models used (G-PUCCINI, UKCA). Section 3 presents $\mathrm{CO}, \mathrm{O}_{3}$ and $\mathrm{O}_{3}-\mathrm{CO}$ correlations as observed by TES and as simulated in the models, as well as an analysis of performance of the models by using the correlation coefficient between the modeled and the observed $\mathrm{O}_{3}-$ $\mathrm{CO}$ correlations $(C)$. Section 4 analyzes the results of a sensitivity analysis that examines whether emissions drive the broad features of the correlations and Sect. 5 discusses potential reasons for differences between the models and TES observations. Finally, the conclusions are presented in Sect. 6 . The purpose of this study is not to separately analyze and explain the detailed features of correlations in all different parts of the globe, but to document global correlation maps that can be used for future model evaluation, and discuss the broad features found, with an emphasis on the possible role of emissions as a driver. 


\section{Datasets}

\subsection{TES satellite data}

The Tropospheric Emission Spectrometer (TES) is a highresolution $\left(0.1 \mathrm{~cm}^{-1}\right)$, infrared, Fourier Transform spectrometer aboard the NASA Aura satellite. Aura satellite follows a polar Sun-synchronous orbit with an equator crossing time at 01:45 and 13:45 local time and has a repeat cycle of 16 days. TES covers a wide spectral range ( 650 to $3050 \mathrm{~cm}^{-1}$ ) and has an averaged nadir footprint of about $5 \mathrm{~km}$ by $8 \mathrm{~km}$ (Beer et al., 2001). The spectral radiances measured by TES are used to retrieve the species's (e.g. $\mathrm{O}_{3}, \mathrm{CO}$ ) mixing ratio profiles using the optimal estimation method (Rodgers, 2000; Bowman et al., 2002, 2006). The retrieved natural logarithm of the mixing ratio profile $\hat{\boldsymbol{x}}$ can be expressed as:

$\hat{\boldsymbol{x}}=\boldsymbol{x}_{a}+\mathbf{A}\left(\boldsymbol{x}-\boldsymbol{x}_{a}\right)+\boldsymbol{\epsilon}$

where $\boldsymbol{x}$ and $\boldsymbol{x}_{a}$ are the natural logarithms of the true atmospheric profile and of the a priori profile respectively, $\mathbf{A}$ is the averaging kernel matrix, expressing the sensitivity of the retrieval to the true state, and $\boldsymbol{\epsilon}$ is the observational error. $\hat{\boldsymbol{x}}, \boldsymbol{x}_{a}$, $\mathbf{A}$ and $\boldsymbol{\epsilon}$ are part of the standard TES product. Also, a master quality flag that we use to exclude bad data points is available with the TES product. $\boldsymbol{x}_{a}$ consists of monthly means produced from MOZART model simulations. The TES products are on 67 vertical levels with a varying layer thickness. In this study we use the version 4 of TES global survey data, each of which consists of data from 16 full orbits.

TES $\mathrm{O}_{3}$ data have been evaluated by comparison to ozonesondes (e.g. Worden et al., 2007; Nassar et al., 2008; Bowman et al., 2009; Boxe et al., 2010), aircraft data (e.g. Richards et al., 2008), and satellite data (OMI/MLS) (e.g. Osterman et al., 2008). These studies show that TES $\mathrm{O}_{3}$ generally has a positive bias that varies between 3-10 ppbv (Nassar et al., 2008) in the troposphere. TES CO has been validated against aircraft data and has been shown to have a slightly negative $(<10 \%)$ bias in midlatitudes and a slightly positive bias $(<10 \%)$ in the tropics (Luo et al., 2007; Lopez et al., 2008). The TES $\mathrm{O}_{3}$ and $\mathrm{CO}$ data have been used extensively to examine a variety of scientific topics (e.g. Parrington et al., 2008; Bowman et al., 2009; Shim et al., 2009; Hegarty et al., 2010), including the investigation of the 3-D $\mathrm{O}_{3}$ radiative forcing as observed from space (Aghedo et al., 2011).

\subsection{G-PUCCINI model data}

G-PUCCINI is the Goddard Institute for Space Studies (GISS) model for Physical Understanding of CompositionClimate INteractions and Impacts (Shindell et al., 2006b). The composition model (including both gases and aerosols) is fully embedded in the GISS modelE climate model (Schmidt et al., 2006). Tropospheric and stratospheric chemistry are simulated simultaneously. Tropospheric chemistry includes basic $\mathrm{NO}_{\mathrm{x}}-\mathrm{HO}_{\mathrm{x}}-\mathrm{O}_{\mathrm{x}}-\mathrm{CO}-\mathrm{CH}_{4}$ interactions as well as PAN, isoprene, alkyl nitrates, aldehydes, alkenes and paraffins. The lumped hydrocarbon family scheme was derived from the Carbon Bond Mechanism-4 (Gery et al., 1989) and from the more extensive Regional Atmospheric Chemistry Model, following Houweling et al. (1998). The stratospheric chemistry includes chlorine- and bromine-containing compounds, and $\mathrm{CFC}$ and $\mathrm{N}_{2} \mathrm{O}$ source gases. The full scheme includes 155 chemical reactions among 55 species. The main additions to the chemistry of the previous versions of G-PUCCINI are (a) the addition of acetone to the hydrocarbons following Houweling et al. (1998), (b) the dependence of polar stratospheric cloud formation on the abundance of nitric acid, water vapor and temperature (Hanson and Mauersberger, 1988), and (c) the addition of a reaction pathway for $\mathrm{HO}_{2}+\mathrm{NO}$ to yield $\mathrm{HNO}_{3}$ (Butkovskaya et al., 2007). Photolysis rates are calculated using the Fast-J2 scheme (Wild et al., 2000; Bian and Prather, 2002), whereas other chemical reaction rate coefficients are from JPL-2000 (Sander et al., 2000). Tracer transport uses a non-diffusive quadratic upstream scheme (Prather, 1986). A full description of the model is given in Shindell et al. (2006b) and references therein.

The G-PUCCINI model has been extensively compared with observations and other models (e.g. Stevenson et al., 2006; Dentener et al., 2006; Shindell et al., 2006b,a; Sanderson et al., 2008; Fiore et al., 2009; Lamarque et al., 2010). It performs well at simulating tropospheric $\mathrm{O}_{3}$ and $\mathrm{CO}$ concentrations, with some strengths and weaknesses that will be highlighted later in the discussion.

We ran the model at a $2^{\circ}$ latitude by $2.5^{\circ}$ longitude horizontal resolution, with increased effective resolution for tracers by carrying higher order moments at each grid box. This configuration has 40 vertical hybrid pressure layers from the surface to $0.1 \mathrm{hPa}(\approx 80 \mathrm{~km})$. Simulations were performed using observed sea-surface temperatures (Rayner et al., 2003) and linear relaxation of winds toward NCEP/NCAR reanalysis (Kalnay et al., 1996). We use present-day anthropogenic emissions for a variety of sectors produced in support of the Intergovernmental Panel on Climate Change (IPCC) Fifth Assessment Report (AR5) (Lamarque et al., 2010). For biomass burning we use data from the Global Fire Emissions Database version 2 (GFED2) (Randerson et al., 2007). Isoprene emissions are a function of vegetation type and leaf area index with responses to temperature and solar radiation based on the algorithm of Guenther et al. $(1995,2006)$. Vegetation emissions of alkenes and paraffin come from the GEIA dataset, and are based on Guenther et al. (1995). Lightning $\mathrm{NO}_{\mathrm{x}}$ emissions depend on the climate model's convection based on the parameterization of Price et al. (1997). The abundances of long-lived species (including methane) have been prescribed to observations. 


\subsection{UKCA model data}

UKCA is the UK Chemistry Aerosol Model (Morgenstern et al., 2009; O'Connor et al., 2011), which is based upon the UK Met Office's Unified Model (UM) (Staniforth et al., 2005). We employ the model set up of Telford et al. (2010) who used the tropospheric version of the model (O'Connor et al., 2011). This has a medium-sized chemistry, simulating the $\mathrm{NO}_{\mathrm{x}}, \mathrm{HO}_{\mathrm{x}}$ and $\mathrm{O}_{\mathrm{x}}$ chemical cycles and the oxidation of $\mathrm{CO}$, ethane, propane and isoprene, with 132 reactions among 60 species. Long-lived tracers, such as methane, are set to constant values throughout the atmosphere and $\mathrm{O}_{3}$ and $\mathrm{NO}_{\mathrm{x}}$ are overwritten above $30 \mathrm{hPa}$ with zonal mean values from the Cambridge 2-D model (Law and Pyle, 1993). Photolysis rates are calculated using the offline scheme of Law et al. (1998). Tracer transport is performed using the semiLagrangian scheme of Priestley (1993). An evaluation of the tropospheric version of the model can be found in O'Connor et al. (2011).

We ran the model at a $2.5^{\circ}$ latitude by $3.75^{\circ}$ longitude horizontal resolution. This configuration has 60 vertical hybrid height layers from the surface to $84 \mathrm{~km}$. Simulations were constrained by sea-surface temperatures (Rayner et al., 2003) and with winds and temperature "nudged" (Telford et al., 2008) toward ECMWF Operational analyses. We use the IPCC AR5 emissions inventory from 2000 for both the anthropogenic and biomass burning emissions (Lamarque et al., 2010). Biogenic emissions of isoprene are from Guenther et al. (1995) and there are $40 \mathrm{Tg}$ of acetone emitted per year, spatially distributed as the isoprene emissions (O'Connor et al., 2011). In addition, there are $45 \mathrm{Tg}$ of CO emitted from the oceans and $18.4 \mathrm{Tg}$ of NO emitted from soils with distributions taken from the GEIA project ${ }^{1}$. Lightning $\mathrm{NO}_{\mathrm{x}}$ emissions depend on the climate model's convection based on the parameterization of Price and Rind (1994).

\subsection{Data post-processing}

Similarly to when comparing TES data with in-situ measurements (sondes, aircraft; e.g. see Jones et al. (2003); Worden et al. (2007); Shim et al. (2009)), we have post-processed the model output in order to be directly comparable with the TES observations. This required: (i) sampling of the model 3-hourly output at the times and locations of the TES measurements, (ii) interpolating model data onto the 67 TES vertical pressure levels, and (iii) application of the TES a priori profiles and averaging kernels (hereafter, "TES operators"), in order to account for the measurement sensitivity (see Sect. 2.1) at different times and locations. Step (iii) involves the use of Eq. (1), but with the logarithm of the mixing ratios from the model (extracted and vertically interpolated) now replacing the true atmospheric profile. When the averaging kernel goes to zero, the model post-processed output

\footnotetext{
${ }^{1}$ http://www.geiacenter.org/inventories/present.html
}

will revert to the a priori profile values, as would the TES measurements. TES has been shown to be relatively sensitive in the vertical region on which we are focusing in this study $(800-400 \mathrm{hPa})$, in several different geographical areas (Zhang et al., 2006; Worden et al., 2007; Richards et al., 2008; Osterman et al., 2008; Bowman et al., 2009; Shim et al., 2009; Hegarty et al., 2009).

Note that we have binned the processed observational and model data onto a $4^{\circ}$ latitude by $5^{\circ}$ longitude grid in order to smooth-out gaps in the observations. A similar smoothing was done in the correlation analysis of Zhang et al. (2006), but on a coarser grid $\left(10^{\circ} \times 10^{\circ}\right)$, since they considered only one month.

\section{Results from TES and models}

Figures 1 and 2 show the mean concentrations of $\mathrm{CO}$ and $\mathrm{O}_{3}$ for the period of interest (2005-08) and for the two seasons of interest (July-August and December-January, respectively). From Fig. 1, it is obvious that both models are able to capture the $\mathrm{CO}$ spatial variability fairly well: the northern hemispheric concentrations are much higher, and the biomass burning peaks are clearly visible for both seasons. Also, CO is more abundant in the Northern Hemisphere winter, which is reasonable due to the lower amounts of hydroxyl radical $(\mathrm{OH})$ that are present in the troposphere in that season (reduced oxidizing capacity). The average $\mathrm{CO}$ concentrations in both models are higher than in TES for both seasons. This is in contrast to earlier results from a multimodel study (Shindell et al., 2006a), which found that the majority of models under-predicted $\mathrm{CO}$ in the troposphere, especially at boreal latitudes. Our result suggests that probably the new anthropogenic emissions dataset that we are using (AR5) includes improved emission estimates. Also, the differences between modeled and measured $\mathrm{CO}$ may have to do with the low biases of TES CO (see Sect. 2.1) especially at midlatitudes.

The spatial distribution of $\mathrm{O}_{3}$ in TES is captured well by the models (Fig. 2): there is high $\mathrm{O}_{3}$ in anthropogenically polluted and biomass burning regions, and over the former, $\mathrm{O}_{3}$ is highest in the summer, when photochemical activity is at its peak. Also, the highest values of ozone in the summertime are seen over Middle East, North Africa and central Asia in all datasets, consistent with previous studies for the middle troposphere (Liu et al., 2009; Worden et al., 2009). The G-PUCCINI model captures the levels of $\mathrm{O}_{3}$ very well, in agreement with what Shindell et al. (2006b) found for the middle troposphere. In the UKCA model, the spatial pattern is captured well, though the $\mathrm{O}_{3}$ levels appear to be somewhat lower than the observed. However, note that TES $\mathrm{O}_{3}$ has been found to be positively biased (see Sect. 2.1) in much of the globe, which implies that the UKCA is likely doing well, and better than this comparison implies. 


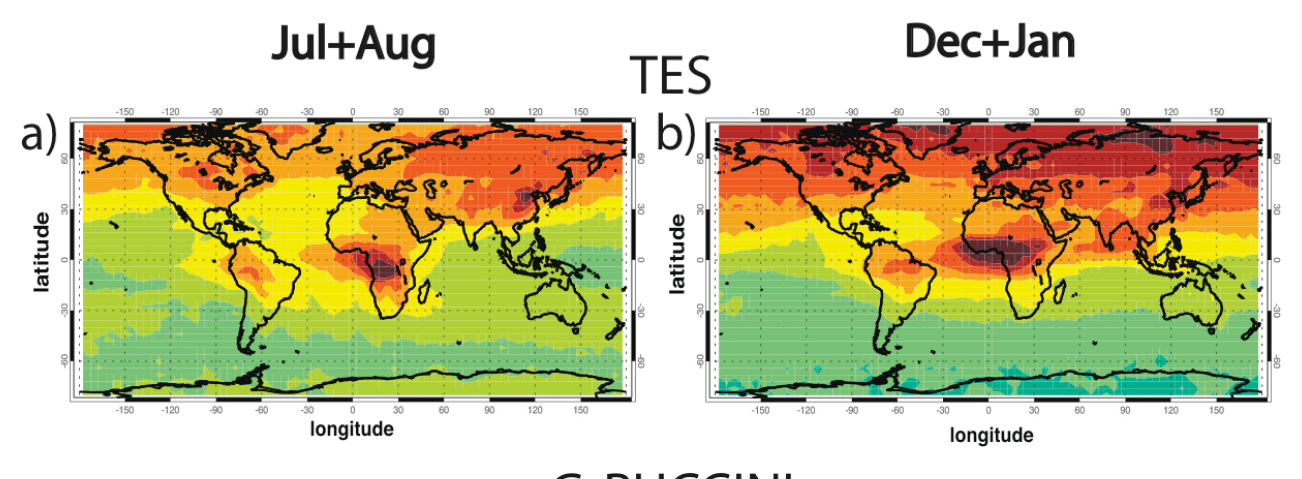

G-PUCCINI
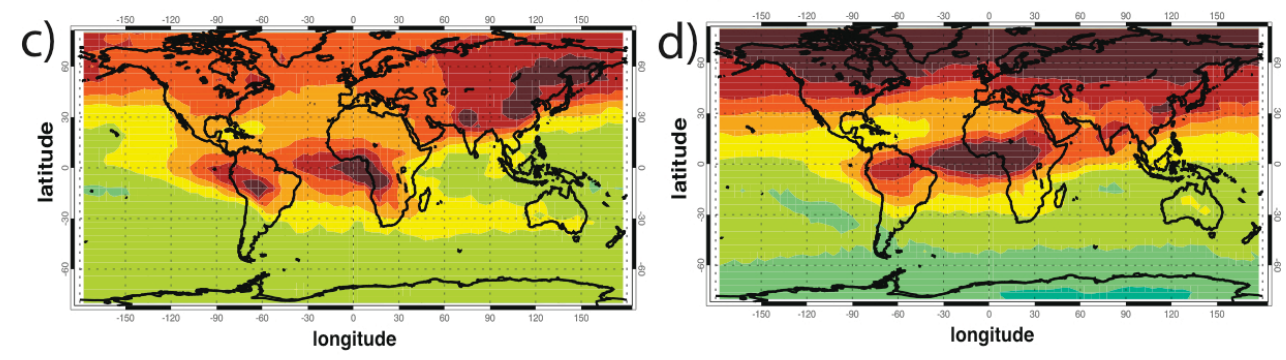

UKCA

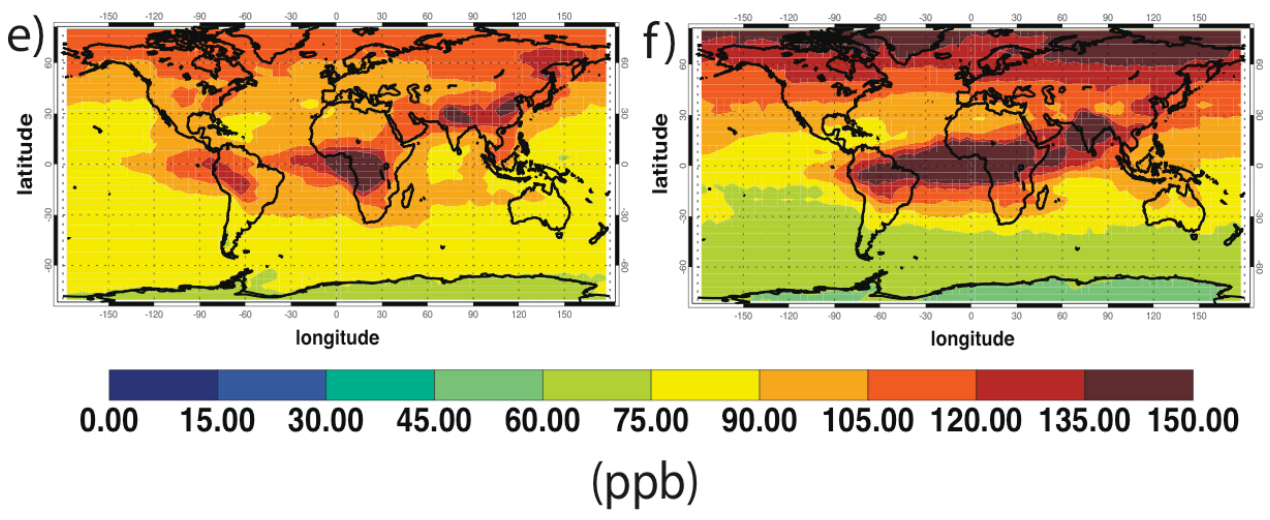

Fig. 1. Mean 2005-08 middle/lower free tropospheric CO concentrations for TES (a, b), G-PUCCINI (c, d) and UKCA (e, f) in July-August (left panels) and December-January (right panels). We used data from 7 TES pressure levels between 800 and $400 \mathrm{hPa}$. TES sampling and operators have been applied to the model output. The data have been smoothed by averaging on a $4 \times 5$ degree grid.

Figure 3 shows global maps of the correlation coefficients between the 2005-08 $\mathrm{O}_{3}$ and $\mathrm{CO}$ time series (daily means), as observed from TES and as simulated by the two models, for the two seasons of interest. In the TES map for JulyAugust (panel a), it can be seen that several regions have positive correlations, with the highest ones being in the western part of the northern Pacific (up to 0.8). Positive summer $\mathrm{O}_{3}-\mathrm{CO}$ correlations were also found in in-situ measurements within this region (e.g. Kajii et al., 1998; Mauzerall et al., 2000; Suthawaree et al., 2008). In our study, positive but lower correlations also extend further East, towards the US. In fact, the positive correlations are also found over the US, and become reinforced over the other major midlatitude pollution outflow region, from the east US coast towards the northern Atlantic, where we find positive correlations of up to 0.4-0.6. Positive summer $\mathrm{O}_{3}-\mathrm{CO}$ correlations in this area are also in agreement with previous studies (e.g. Parrish et al., 1993, 1998; Honrath et al., 2004).

Other regions that stand out as areas of positive $\mathrm{O}_{3}-\mathrm{CO}$ correlations include a big part of the tropics and subtropics, especially close to biomass burning regions. These areas have not been examined in detail in terms of the $\mathrm{O}_{3}-\mathrm{CO}$ correlation in the past, but two studies for spring by Collins et al. (1996) (southern Atlantic) and by Shim et al. (2009) (Gulf of Mexico) revealed positive correlations. Also, positive correlations were found during fire events in northern Australia (Takegawa et al., 2003) and at a mountain site in Kenya (Henne et al., 2008), though in the latter correlations were weak. 


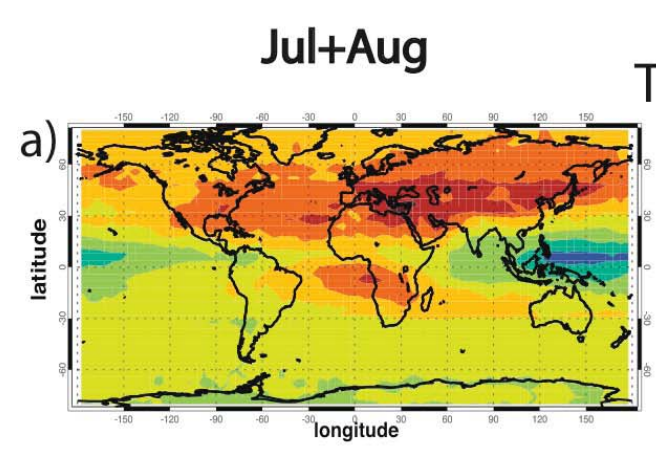

Dec+Jan

TES

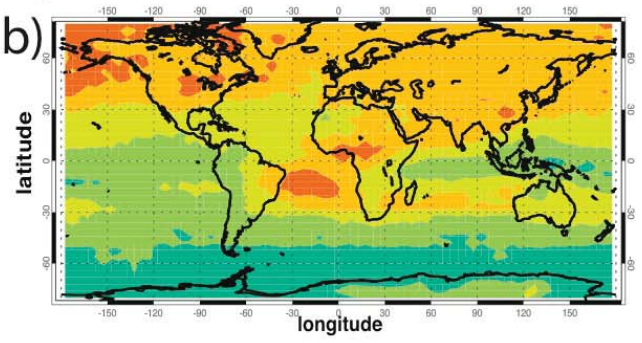

G-PUCCINI
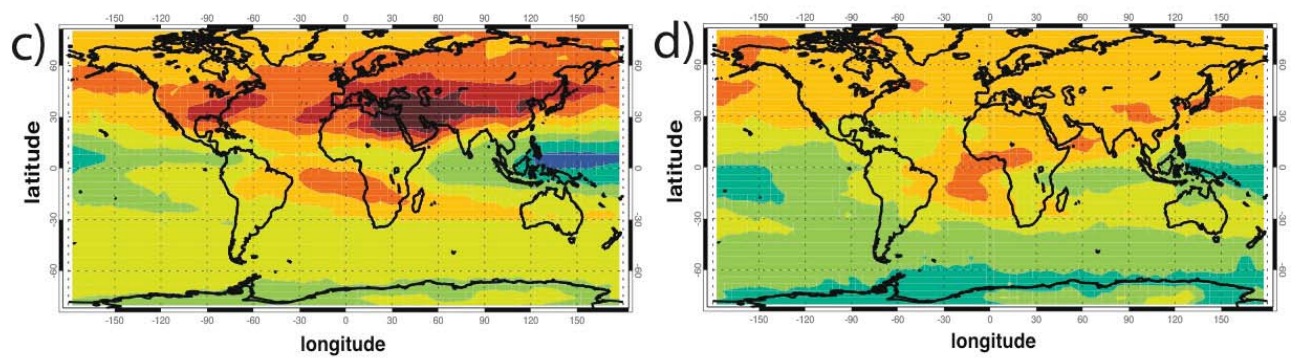

UKCA
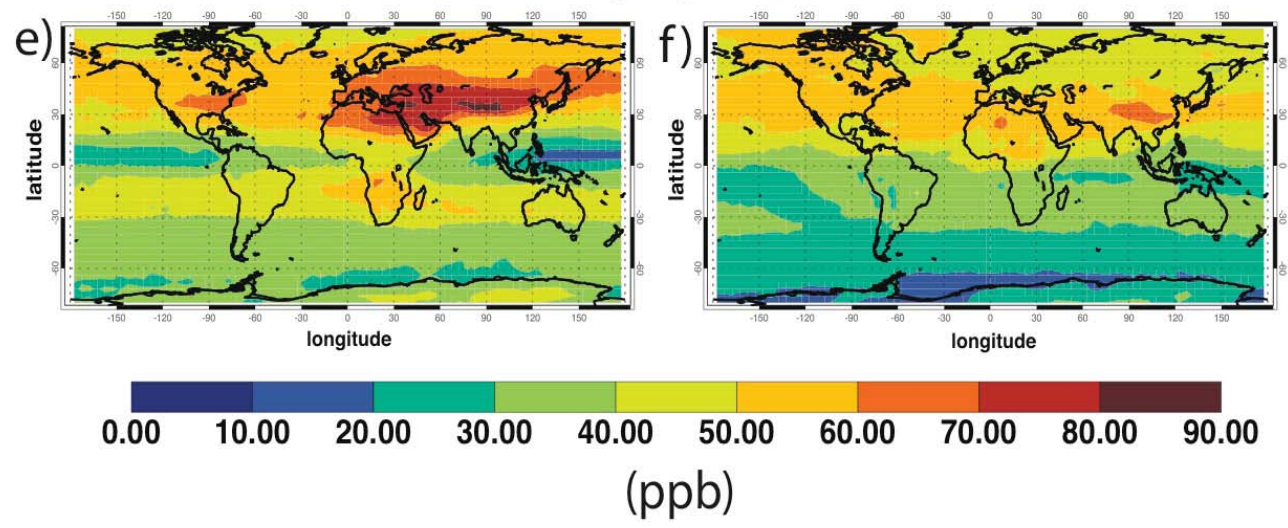

Fig. 2. Mean 2005-08 middle/lower free tropospheric $\mathrm{O}_{3}$ concentrations for TES (a, b), G-PUCCINI (c, d) and UKCA (e, f) in July-August (left panels) and December-January (right panels). We used data from 7 TES pressure levels between 800 and $400 \mathrm{hPa}$. TES sampling and operators kernels have been applied to the model output. The data have been smoothed by averaging on a $4 \times 5$ degree grid.

Areas of negative correlations in July-August include high northern latitudes and the deserts of the Sahara and the Middle East (regions not studied in terms of $\mathrm{O}_{3}-\mathrm{CO}$ correlation in the past). Also, much of continental Asia shows negative or weak correlations, in agreement with Naja et al. (2003); Wang et al. (2006), while areas closer to the large urban centers of East Asia show mainly positive correlations, in agreement with Gao et al. (2005); Wang et al. (2008); Ding et al. (2009). Apart from qualitatively agreeing fairly well with past in-situ observational studies, the TES $\mathrm{O}_{3}$-CO correlation patterns that we find also broadly agree with the findings of Zhang et al. (2006) for July 2005 (where they use TES and the GEOS-Chem model).
The positive $\mathrm{O}_{3}-\mathrm{CO}$ correlations found in TES data for the midlatitude pollution outflow regions in the summer, are still found in the winter (Fig. 3b), but with less latitudinal coverage, extending mainly up to $30-40^{\circ} \mathrm{N}$. The higher latitude areas in northern Atlantic/Pacific now show negative correlations, in agreement with previous studies (e.g. Parrish et al., 1998; Kajii et al., 1998; Li et al., 2002; Suthawaree et al., 2008). This indicates that these latitudes, due to the lack of sunlight, do not experience intense photochemistry and are dominated by $\mathrm{O}_{3}$ destruction and/or dry deposition. Occasionally, stratosphere-troposphere exchange (STE) can also drive these negative correlations, which, however, is more frequent in spring (Zhang et al., 2008). The tropics show positive correlations in regions where wildfire burning 


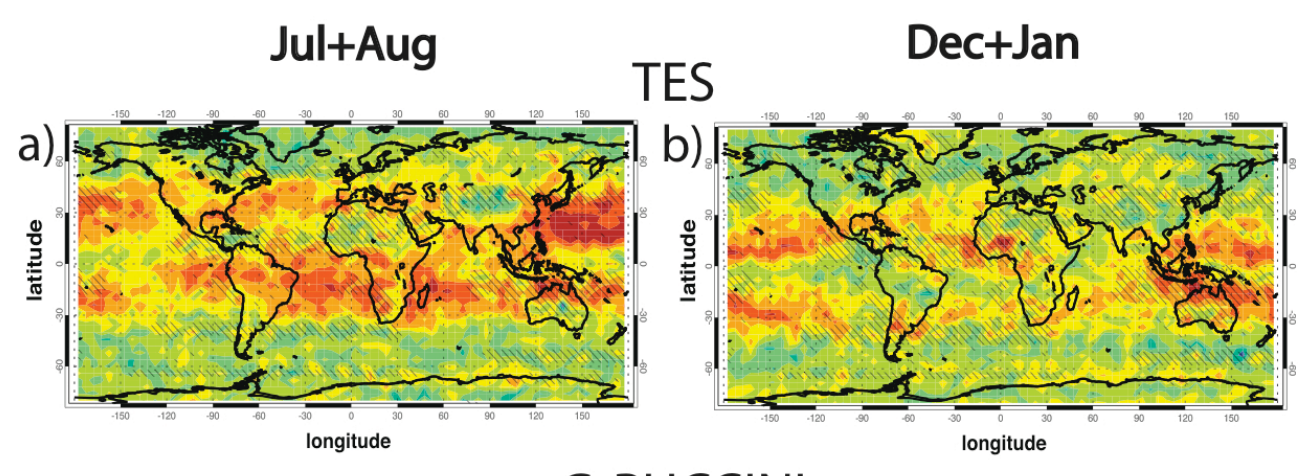

G-PUCCINI
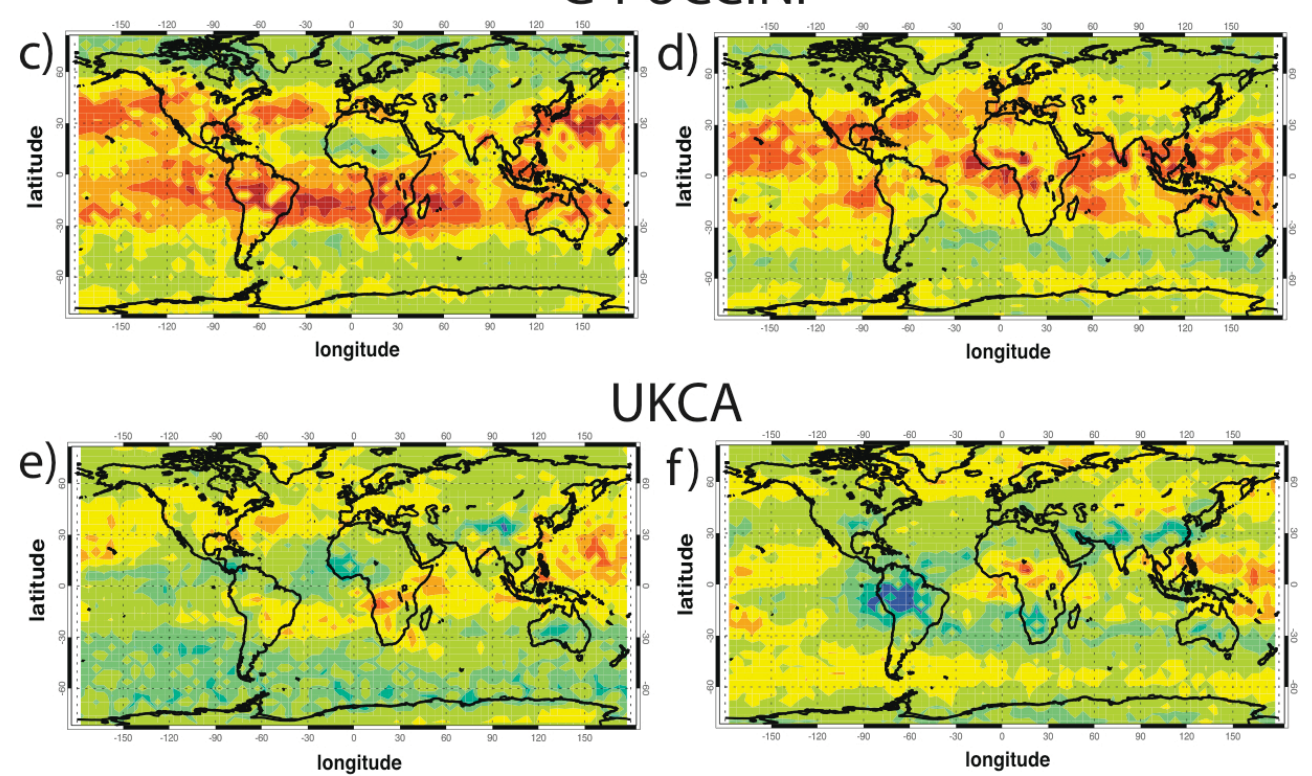

UKCA
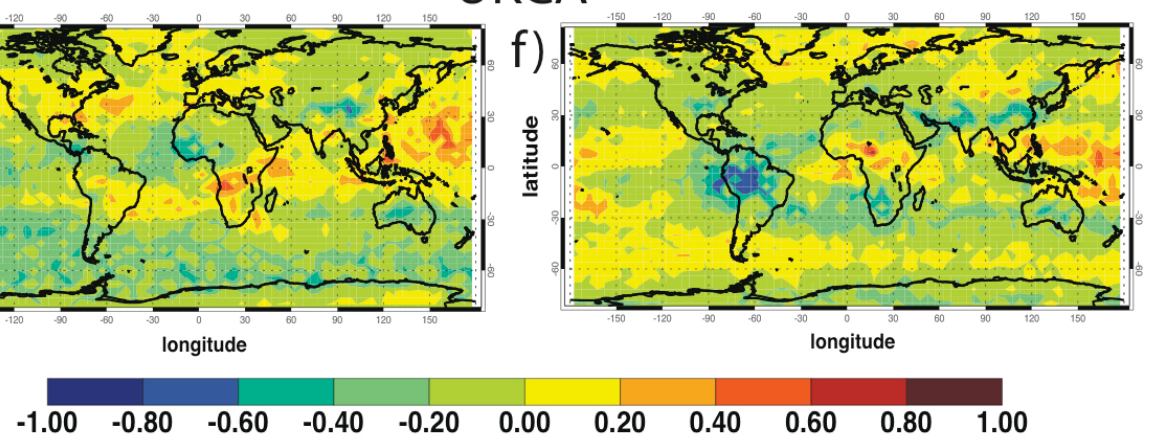

Fig. 3. Correlation coefficient of daily mean 2005-08 middle/lower free tropospheric $\mathrm{O}_{3}$ and CO concentrations for TES (a, b), G-PUCCINI $(\mathbf{c}, \mathbf{d})$ and UKCA (e, f) in July-August (left panels) and December-January (right panels). We used data from 7 TES pressure levels between 800 and $400 \mathrm{hPa}$. TES sampling and operators have been applied to the model output. Also, the observational error has been taken into account for the model correlations, following Eq. (3) of Zhang et al. (2006). Stippling indicates the areas for which less than 40 sample members (i.e. days) were available for the correlation calculation. These are the same (but not shown) in the middle and lower panels (c, d, e, f), since the geographical and temporal sampling was identical with the upper panels. Within these regions with $>40$ sample members, correlations are statistically significant only where they are higher than 0.3 or lower than -0.3 , based on a Pearsons test (95\% confidence interval). The data have been smoothed by averaging on a $4 \times 5$ degree grid.

is expected during the December-January season, like West Africa and a large part of Central Africa. Most of the regions that showed negative correlations in July-August, still have negative correlations in December-January, like, for instance, the northern high latitudes, in agreement with Harris et al. (2000) who studied $\mathrm{O}_{3}$-CO correlations in Alaska during winter.

Apart from the $\mathrm{O}_{3}-\mathrm{CO}$ correlation coefficients, we also calculated the slopes of the TES $\mathrm{O}_{3}-\mathrm{CO}$ regression line, which represent the $\mathrm{O}_{3}$-CO enhancement ratio $\left(d\left[\mathrm{O}_{3}\right] / d[\mathrm{CO}]\right)$ and are shown in Fig. $4 \mathrm{a}$, b. Slopes are useful to indicate the strength of the $\mathrm{O}_{3}-\mathrm{CO}$ relationships, and as such they have been reported in several observational studies (e.g. Parrish et al., 1998; Li et al., 2002). It is clear that the patterns of the slopes follow those of the correlations (Fig. 3a, b) very well. Additionally, in order to understand which regions with high correlations are associated also with high absolute variability of pollution, we calculated the TES $\mathrm{O}_{3}-\mathrm{CO}$ covariance (see Fig. 4c, d), from the same data used for the calculation of the correlation. It is evident that the areas with highest covariance are the biomass burning regions in both seasons and the midlatitude pollution outflow regions 

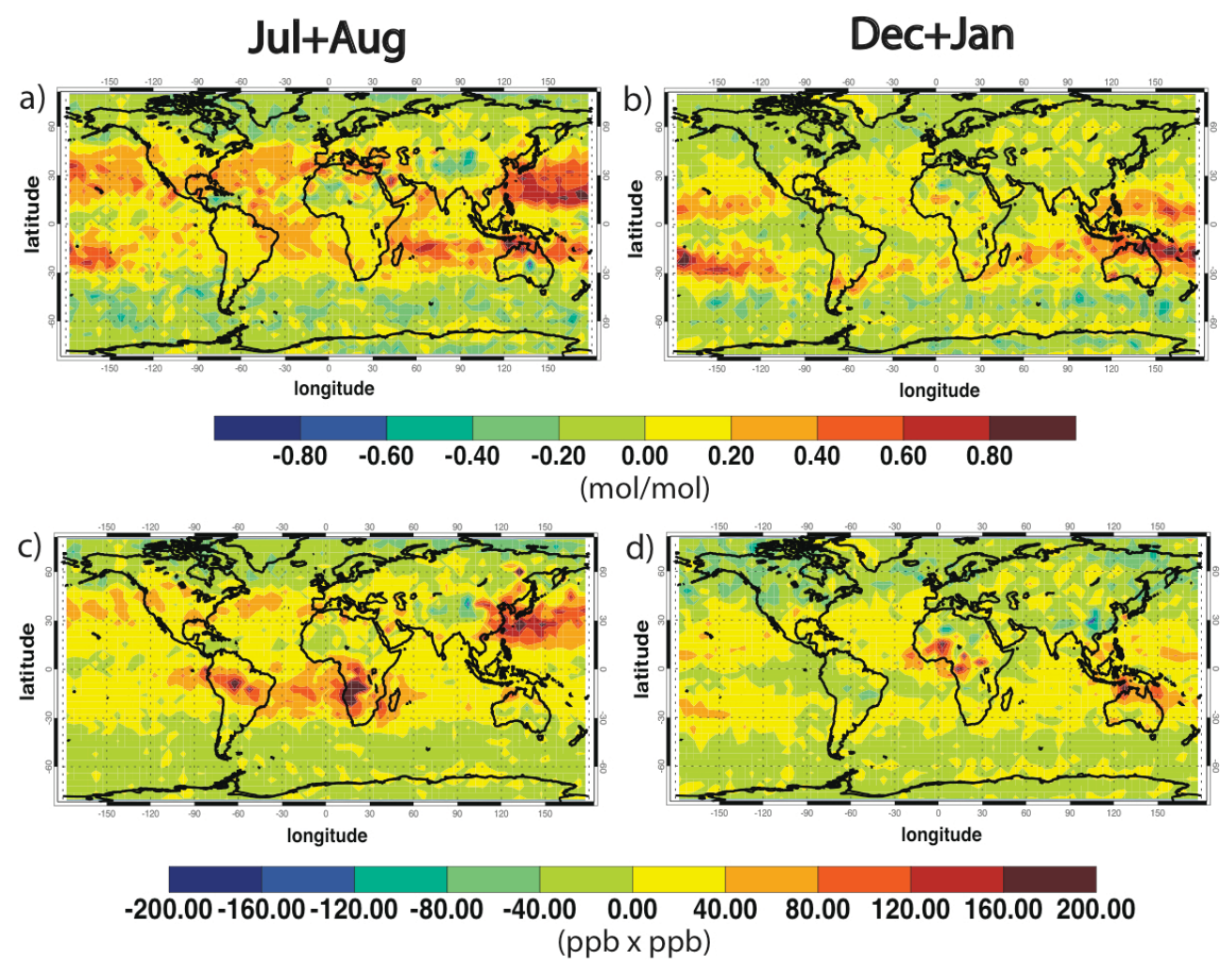

Fig. 4. $\mathrm{O}_{3}-\mathrm{CO}$ slope $(d[\mathrm{O} 3] / d[\mathrm{CO}])(\mathbf{a}, \mathbf{b})$ and covariance $(\mathbf{c}, \mathbf{d})$ from the 2005-08 800-400hPa TES data for July-August (a, c) and December-January $(\mathbf{b}, \mathbf{d})$.

in the Northern-Hemisphere summer. On the other hand, the regions with the lowest absolute covariances cover most of the southern middle/high latitudes $\left(>30^{\circ} \mathrm{S}\right)$ and much of the northern high latitudes $\left(>50^{\circ} \mathrm{N}\right)$, suggesting that any discrepances that we have seen so far regarding the correlation in these regions are not important.

For the calculation of the model $\mathrm{O}_{3}-\mathrm{CO}$ correlations (see Fig. 3c, d, e, f), we have applied the observational error provided from the TES datasets to the model output using the following equation (Zhang et al., 2006):

$$
\operatorname{Corr}\left(\hat{x_{i}} \hat{x}_{j}\right)=\frac{\operatorname{Cov}\left(x_{i}^{\prime} x_{j}^{\prime}\right)}{\sqrt{\sigma_{x_{i}^{\prime}}^{2}+{\overline{x_{i}^{\prime}}}^{2}[S]_{i i}} \sqrt{\sigma_{x_{j}^{\prime}}^{2}+{\overline{x_{j}^{\prime}}}^{2}[S]_{j j}}}
$$

where $\operatorname{Corr}\left(\hat{x}_{i} \hat{x}_{j}\right)$ is the correlation between any two elements $\hat{x}_{i}$ and $\hat{x_{j}}$ of the retrieved model $\mathrm{O}_{3}$ and $\mathrm{CO}$ profiles, $x_{i}^{\prime}$ and $x_{j}^{\prime}$ are the same elements under noise-free conditions, $\operatorname{Cov}\left(x_{i}^{\prime} x_{j}^{\prime}\right)$ is the covariance of these elements, $\overline{x_{i}^{\prime}}$ and $\overline{x_{j}^{\prime}}$ are their mean values, $\sigma_{x_{i}^{\prime}}$ and $\sigma_{x_{j}^{\prime}}$ are their standard deviations, and finally $S$ is the spectral measurement error covariance (we assumed that spectral measurement errors are small in the conversion from log mixing ratio to mixing ratio, and that the spectral measurement error covariance is the same for all scenes, as in Zhang et al., 2006). From the above formula it is clear that the correlations in the raw model data are expected to be higher than those shown in Fig. 3, but the application of the observational error reduced them and made the results directly comparable with TES. This was something that we did not need to do for Fig. 1 and Fig. 2, since on a monthly basis the error is expected to be zero. Note that we performed tests in which the observational error was varied by $\pm 25 \%$, to examine whether the model results depend on this quantity, but found that the main features are fairly insensitive to those perturbations.

G-PUCCINI model results capture many of the correlation patterns seen in the observations remarkably well for both seasons (Fig. 3c, d). There are certain features that are not captured, such as when the correlations become negative in the winter at high-latitudes over the Atlantic, but generally, many of the characteristics are simulated, including the seasonal variation of correlations over the northern Pacific. The UKCA model (Fig. 3e, f) map shows some similarities with TES in terms of distribution of positive and negative correlations. The main difference is that the correlations are systematically lower than the observations for both seasons.

In Fig. 5, we examine the relationship between the modeled and observed $\mathrm{O}_{3}-\mathrm{CO}$ correlations using data from all over the globe. It is evident that the G-PUCCINI model does well in capturing the summer $\mathrm{O}_{3}-\mathrm{CO}$ correlations, while in 

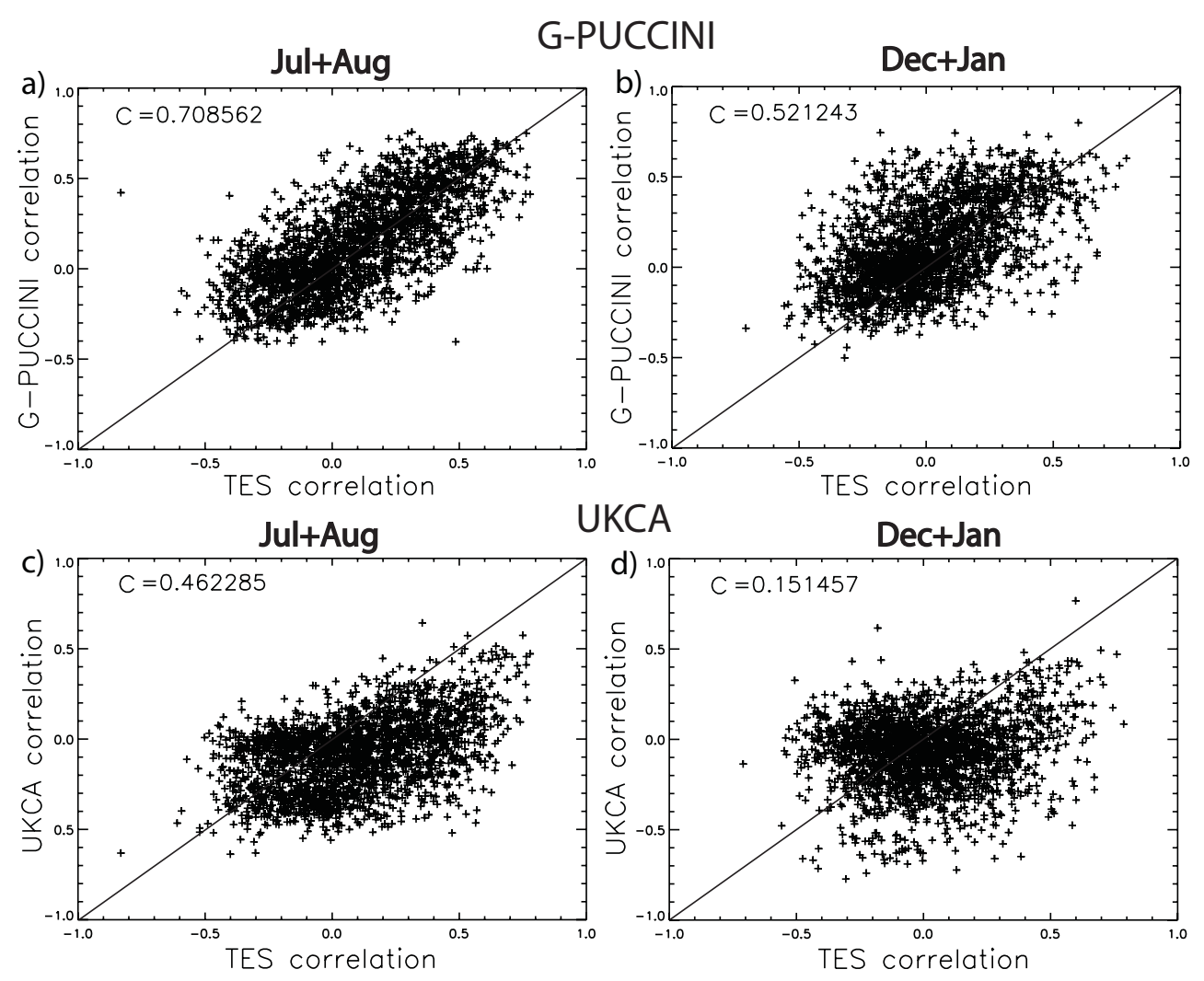

Fig. 5. Scatter plots of modeled versus observed $\mathrm{O}_{3}-\mathrm{CO}$ correlations for July-August (a, c) and December-January (b, d). The data that have been used are the same as for Fig. 3, and have undergone the same processing.

the winter there seems to be a slight tendency for overestimation. The UKCA model tends to underestimate the $\mathrm{O}_{3}$ $\mathrm{CO}$ correlations in both seasons, especially in the summer. Additionally, in order to quantitatively compare the models, we calculate the correlation coefficient $(C)$ between modeled and observed $\mathrm{O}_{3}-\mathrm{CO}$ correlations for different regions of the globe in both seasons (Table 1). It is clear that the areas where the G-PUCCINI model does particularly well cover much of the northern midlatitudes in the summer, with $C$ higher than 0.6 for North America, northern Atlantic, Europe and west northern Pacific. Areas with less good performance can be found in the tropics (e.g. South America, Central Africa), especially in the winter. The performance of the UKCA model is satisfactory for the northern midlatitudes in the summer, e.g. exhibiting a good performance at the Pacific outflow region. However, with the exception of the east northern Pacific, the performance at midlatitudes is not good in the winter. On the other hand, there are specific cases where the UKCA model seems to have more skill on capturing the $\mathrm{O}_{3}-\mathrm{CO}$ correlation, such as in remote regions like South America and the east tropical Pacific in the winter.

\section{Sensitivity analysis}

\subsection{Robustness of results}

As discussed in Sect. 3, to calculate the model correlation coefficients shown in Fig. 3 (c, d, e, f), we have taken into consideration the observational error, in order to have a more consistent comparison with TES correlations. In Fig. 6a, we show how the G-PUCCINI model July-August correlations would look, had we not accounted for this error. As expected, the sign of correlations is identical with Fig. 3c, but the magnitude of correlations is larger. We underline that the magnitude of correlations seen in Fig. 6 a is expected to be closer to what could be found in reality in the troposphere, since the correlations have not been degraded by observational error.

In Fig. 6b, we show how the G-PUCCINI $\mathrm{O}_{3}-\mathrm{CO}$ correlations would look if the TES operators had not been applied to the model output (so that the only post-processing would have been the TES time/location sampling). It is clear that the results are very similar to Fig. 6a, with the exception of the Southern Ocean, where correlations change from negative to positive. This indicates that this region was heavily weighted towards the TES a priori. However, as seen in Fig. $4 c, d$, this is an area with very low $\mathrm{O}_{3}-\mathrm{CO}$ covariance, thus this difference in correlations when ignoring the TES 
Table 1. Performance (using our $\mathrm{C}$ metric) in terms of capturing the $\mathrm{O}_{3}-\mathrm{CO}$ correlations, of the G-PUCCINI and UKCA models at various regions of the globe for two seasons (July-August and December-January). C represents the correlation coefficient between the modeled and the TES $\mathrm{O}_{3}$-CO correlations. The figures in italics are not statistical significant based on a Pearsons test (95\% confidence interval). Note that we have avoided using regions that generally have low data availability (e.g. North Africa) based on Fig. 3a, b.

\begin{tabular}{lrrrr}
\hline & $\begin{array}{r}\text { G-PUCCINI } \\
\text { (Jul+Aug) }\end{array}$ & $\begin{array}{r}\text { UKCA } \\
(\text { Jul+Aug) }\end{array}$ & $\begin{array}{r}\text { G-PUCCINI } \\
\text { (Dec+Jan) }\end{array}$ & $\begin{array}{r}\text { UKCA } \\
\text { (Dec+Jan) }\end{array}$ \\
\hline Global & 0.71 & 0.46 & 0.52 & 0.15 \\
North America $\left(120^{\circ} \mathrm{W}-70^{\circ} \mathrm{W} ; 35^{\circ} \mathrm{N}-65^{\circ} \mathrm{N}\right)$ & 0.70 & 0.33 & 0.32 & -0.49 \\
North Atlantic $\left(70^{\circ} \mathrm{W}-15^{\circ} \mathrm{W} ; 35^{\circ} \mathrm{N}-65^{\circ} \mathrm{N}\right)$ & 0.81 & 0.53 & 0.57 & -0.39 \\
Europe $\left(10^{\circ} \mathrm{W}-35^{\circ} \mathrm{E} ; 35^{\circ} \mathrm{N}-65^{\circ} \mathrm{N}\right)$ & 0.67 & 0.43 & 0.31 & -0.20 \\
Siberia $\left(60^{\circ} \mathrm{E}-130^{\circ} \mathrm{E} ; 45^{\circ} \mathrm{N}-70^{\circ} \mathrm{N}\right)$ & 0.15 & 0.28 & 0.10 & 0.16 \\
West Northern Pacific $\left(130^{\circ} \mathrm{E}-180^{\circ} \mathrm{W} ; 20^{\circ} \mathrm{N}-50^{\circ} \mathrm{N}\right)$ & 0.72 & 0.64 & 0.58 & 0.24 \\
East Northern Pacific $\left(180^{\circ} \mathrm{W}-120^{\circ} \mathrm{W} ; 20^{\circ} \mathrm{N}-50^{\circ} \mathrm{N}\right)$ & 0.40 & 0.30 & 0.68 & 0.50 \\
South America $\left(80^{\circ} \mathrm{W}-35^{\circ} \mathrm{W} ; 30^{\circ} \mathrm{S}-10^{\circ} \mathrm{N}\right)$ & 0.23 & 0.27 & 0.18 & 0.40 \\
South Atlantic $\left(30^{\circ} \mathrm{W}-0^{\circ} \mathrm{E} ; 30^{\circ} \mathrm{S}-0^{\circ} \mathrm{N}\right)$ & 0.35 & 0.04 & 0.22 & -0.04 \\
Central Africa $\left(10^{\circ} \mathrm{E}-40^{\circ} \mathrm{E} ; 20^{\circ} \mathrm{S}-5^{\circ} \mathrm{N}\right)$ & 0.17 & 0.07 & -0.04 & 0.23 \\
Indian Ocean $\left(50^{\circ} \mathrm{E}-90^{\circ} \mathrm{E} ; 30^{\circ} \mathrm{S}-10^{\circ} \mathrm{N}\right)$ & 0.62 & -0.07 & -0.31 & -0.15 \\
West Tropical Pacific $\left(100^{\circ} \mathrm{E}-150^{\circ} \mathrm{E} ; 20^{\circ} \mathrm{S}-20^{\circ} \mathrm{N}\right)$ & 0.40 & 0.24 & 0.17 & 0.28 \\
East Tropical Pacific $\left(130^{\circ} \mathrm{W}-85^{\circ} \mathrm{W} ; 20^{\circ} \mathrm{S}-20^{\circ} \mathrm{N}\right)$ & 0.41 & 0.06 & 0.36 & 0.58 \\
\hline
\end{tabular}

operators is not important, as it is not associated with large enough $\mathrm{O}_{3}$ and $\mathrm{CO}$ fluctuations. Figure $6 \mathrm{c}$ shows how the correlations would look, had there been no TES time/location sampling. The plot indicates that the features of the maps that we have shown so far do not depend on the TES sampling.

Figure $6 \mathrm{~d}$ shows the $\mathrm{O}_{3}$-CO correlations for a single pressure level $(562 \mathrm{hPa})$ within the vertical region of interest (800-400 hPa), rather than for the $800-400 \mathrm{hPa}$ mean. One can conclude that our results do not depend on the choice of height in the middle/lower free troposphere. The results appear to change more when looking at the upper troposphere (see panel (e) for correlations at $316 \mathrm{hPa}$ ), with e.g. correlations getting significantly lower over northern high latitudes, most likely due to the influence of STE. However, there are several features, especially in the northern midlatitudes, that remain similar even at this altitude.

From Fig. 6f, it can be seen that our results do not only apply for day-to-day variations of $\mathrm{O}_{3}$ and $\mathrm{CO}$, but are similar when considering somewhat longer timescales (quasiweekly). Note that we have also tested how the correlations change when taking into account the raw 3-hourly model data instead of the daily averages, and how they change when deseasonalizing the $\mathrm{O}_{3} / \mathrm{CO}$ time series (not shown). Again, little change has been found in our results (expect for deseasonalization effects in the Southern Ocean, which were more drastic, but only when calculating correlations using days from all months of the year). Later in the manuscript (Fig. 8a and Fig. 9a), we also discuss that the $\mathrm{O}_{3}-\mathrm{CO}$ correlations are not sensitive to the year that we choose.

For the UKCA model (Fig. 7), similar conclusions about the robustness of the results can be drawn. There are some notable exceptions, like the fact that when not applying the TES operators to the UKCA post-processing (Fig. 7b), (i) the northern high-latitude $\left(>60^{\circ} \mathrm{N}\right)$ correlations become almost entirely negative, which is more in agreement with the observations, and (ii) the positive correlations over biomass burning regions in Africa become more widespread, which may be related to the fact that the convective processes are different in the two models. This suggests that the observed correlations can provide a useful constraint for vertical mixing, something that can be examined further in future work.

However, in general the correlation features found in our analysis seem to be robust and to characterize each model. Note that the same robustness exists in the observational data (no dependence on year, altitude within $800-400 \mathrm{hPa}$, timescale etc.). Additionally, most of the similarities found across different estimates, as described in Fig. 6 and Fig. 7 for July-August, are also present in G-PUCCINI/UKCA results for December-January. In Fig. $6 \mathrm{~g}$ and Fig. $7 \mathrm{~g}$ we show the 2005-08 December-January correlations from the raw model output (compare with Fig. 3d and Fig. 3f) just for reference. Despite the similarities of the results from all the different ways of estimating the $\mathrm{O}_{3}-\mathrm{CO}$ correlations within each model, the results from the two different models remain significantly different.

\subsection{Perturbing emissions}

Next, we analyze the results of four sensitivity model runs that were performed in order to assess the role of emissions in driving the correlation patterns. We focus on July-August, as we have demonstrated that this is the period with the most intense features in the Northern Hemisphere. Through tests that we have performed by comparing the $\mathrm{O}_{3}$-CO correlations of 2005-08 with those from each individual year (e.g. compare Fig. 8a with Fig. 6c) we have found that the choice 

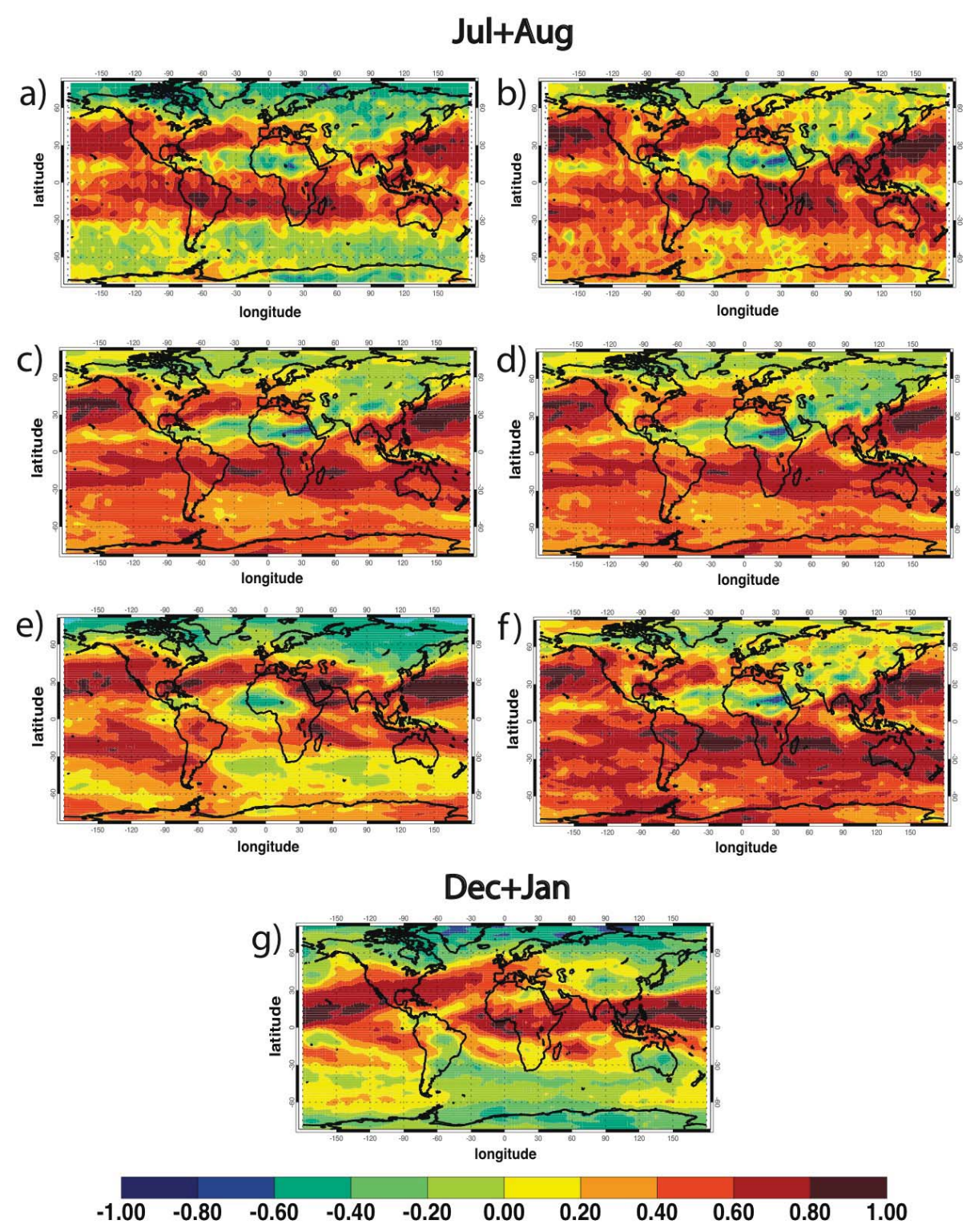

Fig. 6. Testing the robustness of G-PUCCINI 2005-08 correlation coefficients seen in Fig. 3: (a) same as Fig. 3c but without the observational error; (b) same as (a) but without the TES operators application; (c) same as (b) but without the TES sampling (i.e. raw model output); (d) same as (c) but for $562 \mathrm{hPa}$ instead of $800-400 \mathrm{hPa}$ average; (e) same as (c) but for $316 \mathrm{hPa}$ instead of $800-400 \mathrm{hPa}$ average; (f) same as (c) but calculated using 5-daily (quasi-weekly) averages instead of daily. Also, we show the correlations from the raw model output for December-January in (g) (compare with Fig. 3d).

of year does not matter much. So we performed the sensitivity experiments only for year 2006.

In each of the runs, one type of emission is "switched off" (no_ANTH for no anthropogenic, no_BB for no biomass burning, no_LIGHT for no lightning and no_VEG for no vegetation emissions). Figure 8a and Fig. 9a show the results from the unperturbed runs (BASE) in 2006.

In both models, it is clear that biomass burning is the emission that has the highest impact on the $\mathrm{O}_{3}-\mathrm{CO}$ correlation in the tropics (Fig. 8c, Fig. 9c). Downwind of Central Africa and of South America, there is even a change in the sign of the correlation coefficients (from positive to negative). This implies that the photochemistry of these regions heavily depends on biomass burning. We expect that in DecemberJanuary, the large impact of biomass burning will be seen in north equatorial Africa, where biomass burning is intense during that season. It is interesting to note that biogenic emissions (which are very important in the tropics) are not enough to sustain positive correlations in a large part of these regions. There appear to be some regions of positive changes 


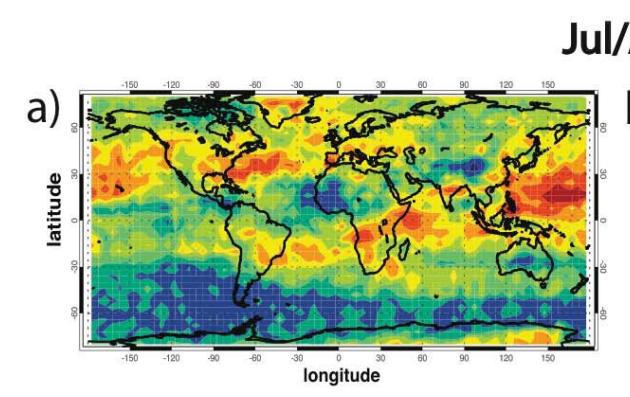

\section{Jul/Aug}
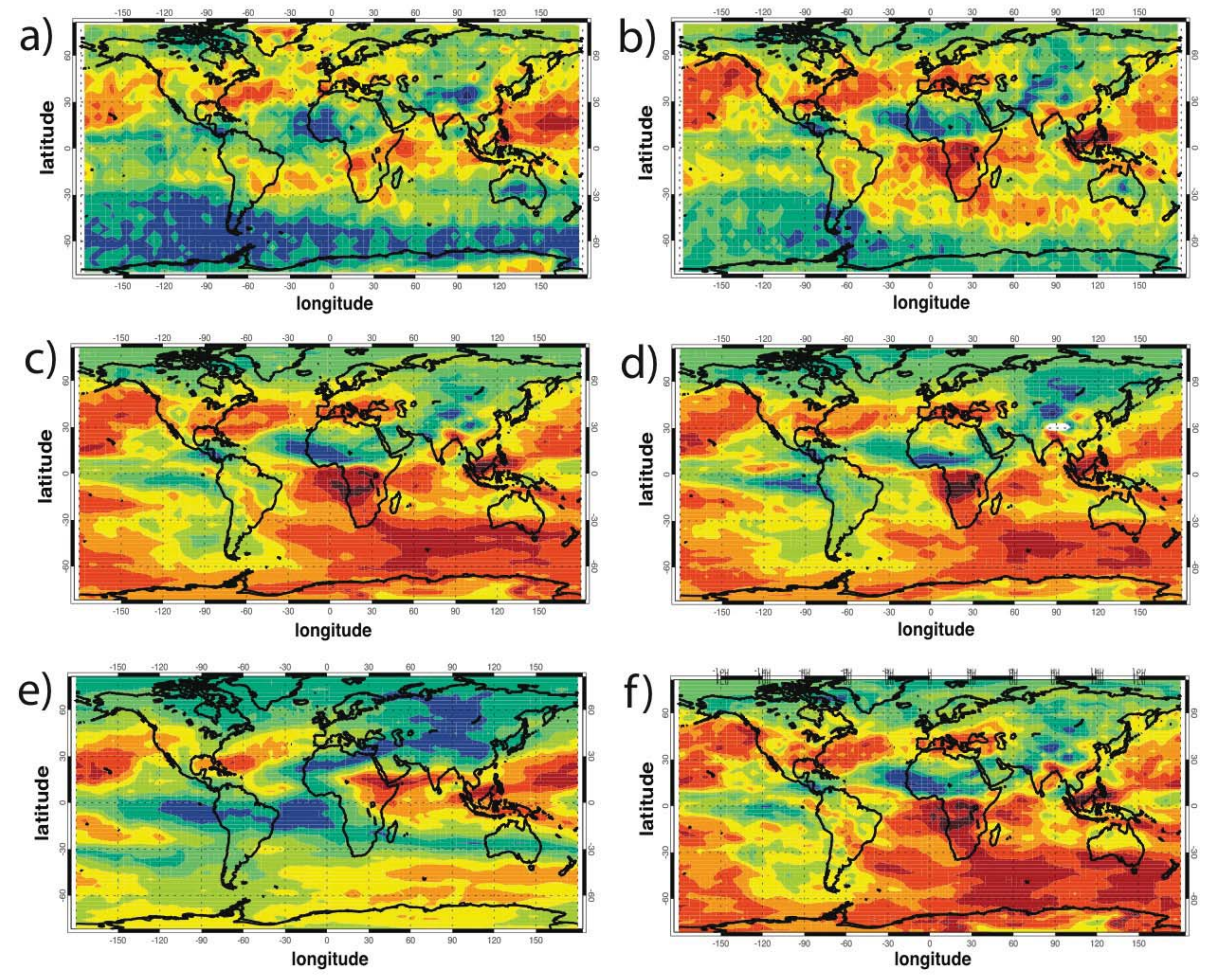

Dec+Jan

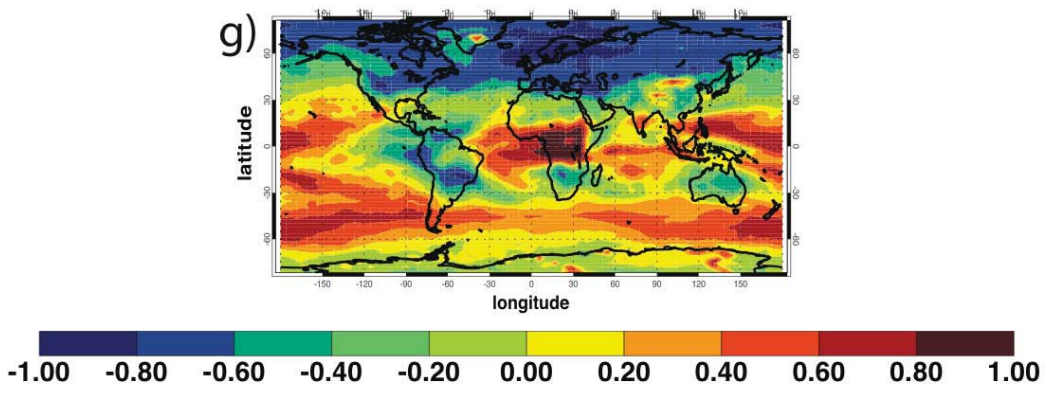

Fig. 7. Testing the robustness of UKCA 2005-08 correlation coefficients seen in Fig. 3: (a) same as Fig. 3e but without the observational error; (b) same as (a) but without the TES operators application; (c) same as (b) but without the TES sampling (i.e. raw model output); (d) same as (c) but for $562 \mathrm{hPa}$ instead of $800-400 \mathrm{hPa}$ average; (e) same as (c) but for $316 \mathrm{hPa}$ instead of $800-400 \mathrm{hPa}$ average; (f) same as (c) but calculated using 5-daily (quasi-weekly) averages instead of daily. Also, we show the correlations from the raw model output for December-January in (g) (compare with Fig. 3f).

in the correlation coefficient in both models, like the outflow regions of pollution from Indonesia (Indian Ocean and equatorial Pacific). These are mostly areas with positive and in some cases high correlations, which become even higher following this perturbation.

The effect of the anthropogenic emissions (Fig. 8b, Fig. 9b) is more straightforward, especially at midlatitudes, where we find mostly reductions in the $\mathrm{O}_{3}-\mathrm{CO}$ correlations when removing them. An exception, in the G-PUCCINI model, is some parts of East Asia, which possibly are dom- inated by $\mathrm{NO}_{\mathrm{x}}$ titration, where correlations are increased in the no_ANTH run. However, this feature is not seen in the UKCA model. Note that in the no_ANTH run, correlations preserve their sign in most of the regions, indicating that there are still other types of emissions in key areas (e.g. biogenic, for the north Atlantic) that preserve the $\mathrm{O}_{3}$ production processes. In the no_VEG run (panels d), correlations are again reduced in regions like, for example, the north Atlantic Ocean, but do not change sign. There are regions where positive correlations increase, like in the west coast of South 


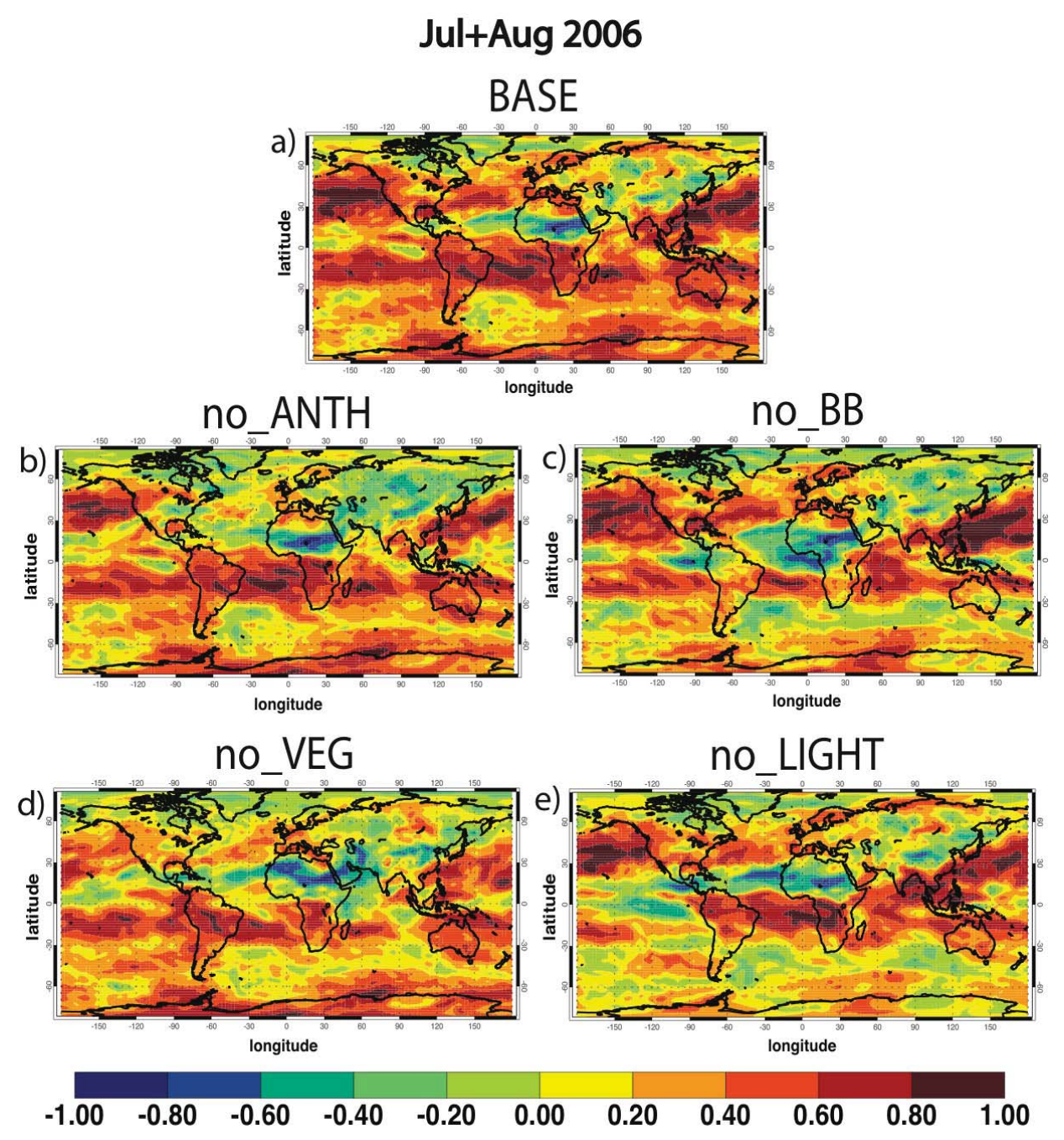

Fig. 8. Correlation coefficient of daily mean July-August 2006 middle/lower free tropospheric $\mathrm{O}_{3}$ and CO concentrations in the BASE G-PUCCINI run (unperturbed; a) and in 4 sensitivity runs in summer. The four runs are: (b) no anthropogenic emissions, (c) no biomass burning emissions, (d) no emissions from vegetation (isoprene, alkenes, paraffin), and (e) no lightning emissions. All model data that fall into the $800-400 \mathrm{hPa}$ region have been used (no time sampling/averaging kernel application).

America, an effect which is rather pronounced in the UKCA model. In general, we can claim that the no_VEG run produced the most uncertain results.

The perturbation of lightning in the no_LIGHT runs (Fig. 8e, Fig. 9e) changes the $\mathrm{O}_{3}$-CO correlation in various areas in the G-PUCCINI model, like the eastern Pacific and the Indian Ocean, but it does not affect substantially the correlations in the UKCA model. This result initiated an examination of the lightning parameterization in the UKCA model, which revealed that lightning $\mathrm{NO}_{\mathrm{x}}$ is emitted at too low tropospheric levels in the model. This may explain the low correlations shown for the UKCA model in Fig. 3 for some of the regions, but not everywhere, as lightning does not seem to be a major driver in areas like the midlatitude outflow regions (see Fig. 8e).

\section{Discussion}

Had we found an emission type with a large impact on GPUCCINI correlations, but not on UKCA, and with a large impact on regions with high correlations (midlatitude continental outflow regions, tropical biomass burning regions) we would have concluded that the treatment of particular types of emissions in the UKCA model (either the emissions themselves or their chemical fate in the troposphere) is the reason for its lower correlations in important areas. Note that we performed an extra experiment with removed VOC emissions (not shown) which showed that there are not drastic changes in the correlations when applying such a perturbation. This rulled out the possibility that the different lumping of VOCs in the two models could make a large difference. 


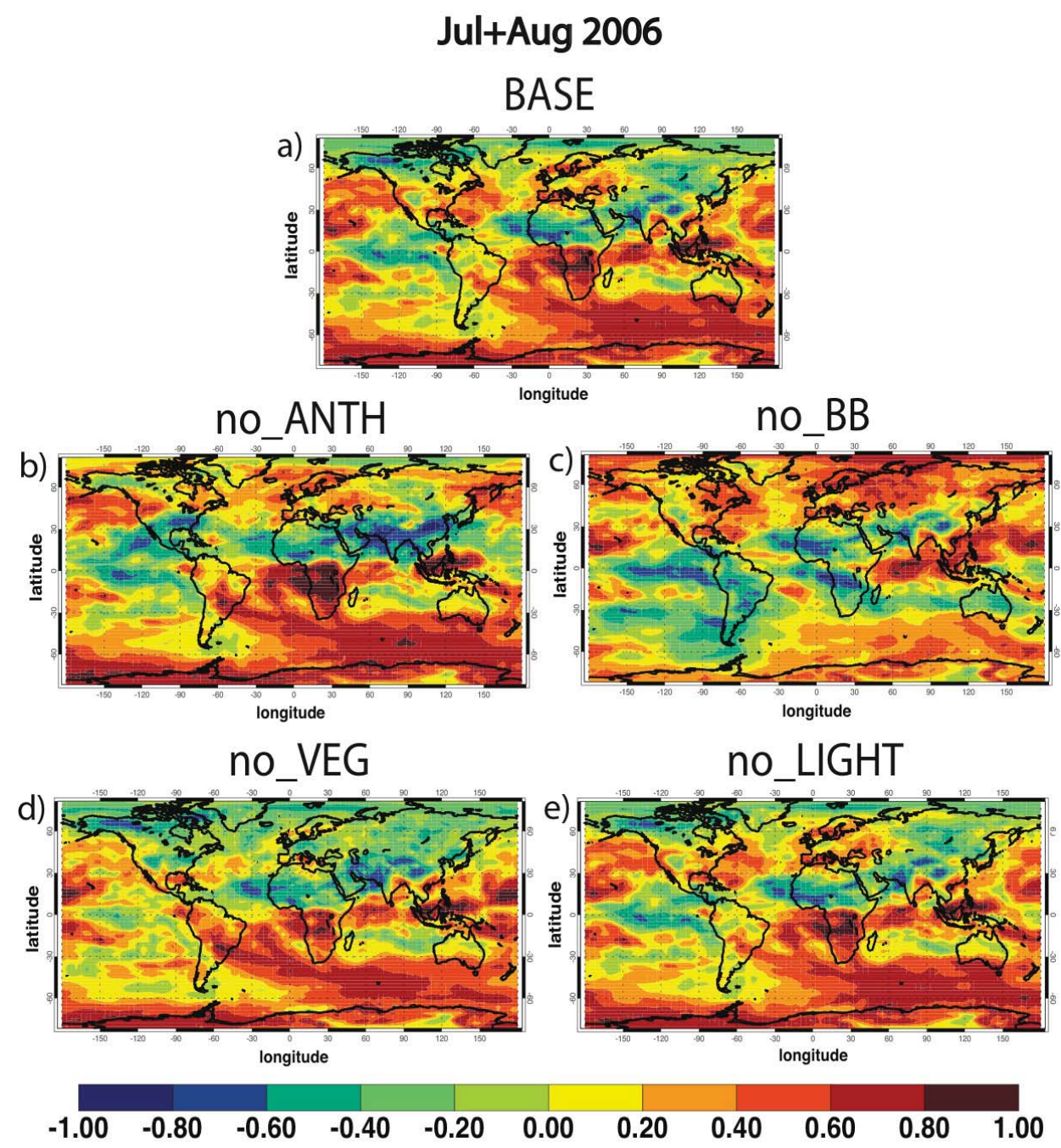

Fig. 9. Correlation coefficient of daily mean July-August 2006 middle/lower free tropospheric $\mathrm{O}_{3}$ and CO concentrations in the BASE UKCA run (unperturbed; a) and in 4 sensitivity runs in summer. The four runs are: (b) no anthropogenic emissions, (c) no biomass burning emissions, (d) no emissions from vegetation (isoprene and acetone), and (e) no lightning emissions. All model data that fall into the 800$400 \mathrm{hPa}$ region have been used (no time sampling/averaging kernel application).

From the above, we conclude that the discrepancies most likely have to do with other factors. This is supported by the fact that the net chemical tendencies (total $\mathrm{O}_{3}$ chemical production minus total ozone chemical loss) in $800-400 \mathrm{hPa}$ (Fig. 10) do not differ much in terms of sign in the crucial regions that we have examined (northern Atlantic, northern Pacific, tropical Africa). In fact, both models show net chemical $\mathrm{O}_{3}$ destruction in large parts of the regions where we have found substantial positive $\mathrm{O}_{3}-\mathrm{CO}$ correlations. This indicates that, contrary to what is often stated, positive $\mathrm{O}_{3}-\mathrm{CO}$ correlations cannot always be used as an indication for local photochemical $\mathrm{O}_{3}$ production. In areas like the northern Pacific, we expect that frequent meridional transport of low-CO/low- $\mathrm{O}_{3}$ air from lower latitudes could be playing a central role.
Increased STE in the UKCA model could have explained the lower $\mathrm{O}_{3}-\mathrm{CO}$ correlations, especially at midlatitudes. However, global STE for 2006 in the model is $659 \mathrm{Tg} \mathrm{yr}^{-1}$, which is well within reported ranges (e.g. Stevenson et al., 2006). In fact, the global downward flux of $\mathrm{O}_{3}$ from a surface $(380 \mathrm{hPa})$ right above our region of interest $(800-400 \mathrm{hPa})$ is $20-30 \%$ lower in the UKCA model compared to the GPUCCINI model. Apart from the influence of vertical mixing, we also expect that horizontal mixing can impact the correlations and their differences in the models. Additionally, convection can also be a source of differences. It is common that models forced with the same meteorology may simulate vertical transport of pollution in the tropics very differently, depending on the parameterization used (Hoyle et al., 2010), while very similar (or the same) models can produce 


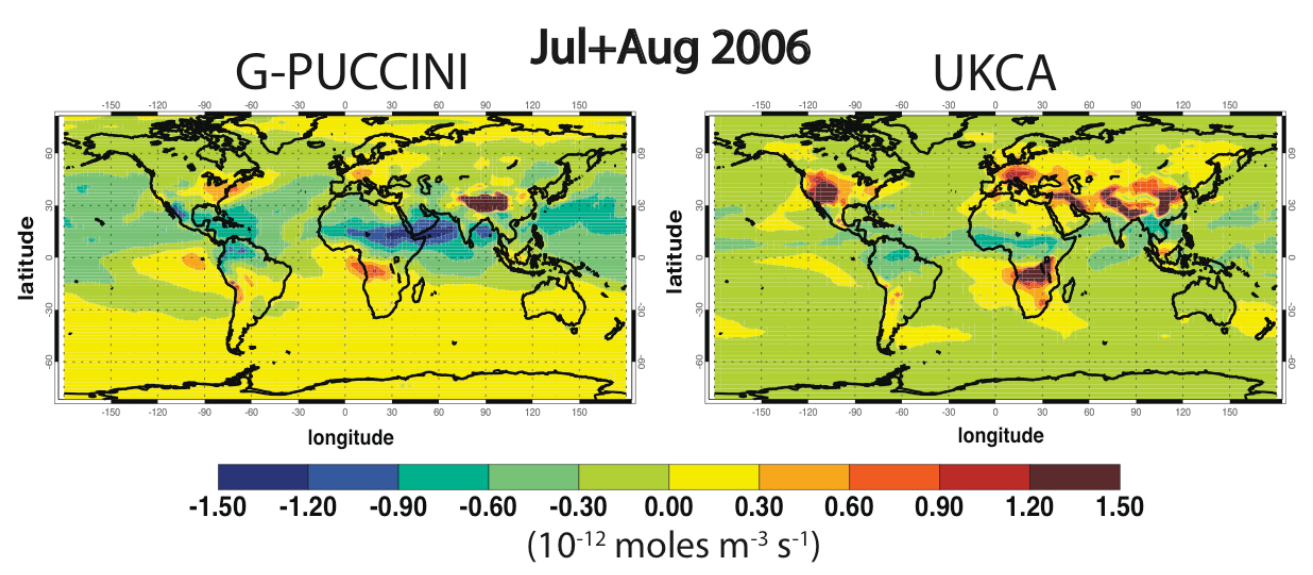

Fig. 10. Net chemical tendency of middle/lower free tropospheric (800-400 hPa) $\mathrm{O}_{3}$ in July-August 2006 for the G-PUCCINI and UKCA unperturbed runs (BASE).

different results when forced with different meteorological analyses (Liu et al., 2010). In fact, the former study notes that nudged models, including UKCA, can misrepresent convective fluxes due to misrepresentation of surface fluxes, such as moisture, even if the large scale circulation is well represented. This was evidenced in too small a flux of idealised tracers in the UKCA model in the West African monsoon.

Another factor that can be driving the differences between the models is the use of an offline photolysis scheme in the UKCA versus an interactive photolysis scheme in GPUCCINI. As found in Voulgarakis et al. (2009a,b), the effects of clouds on photolysis can drive sizeable changes in the chemistry, with impacts being stronger above and below clouds. Even when these effects are above/below our region of interest (800-400 hPa), they can still be affecting our results via transport of signals.

Apart from being a useful addition to future model intercomparisons, the method presented here will be an invaluable way of evaluating the next improved version of the UKCA model and understanding how its recent developments (FastJX photolysis, more realistic lightning $\mathrm{NO}_{\mathrm{x}}$; not included here) impact its ability to simulate tropospheric chemistry.

\section{Conclusions}

We used TES satellite observations and two different models to provide the first global $\mathrm{O}_{3}$-CO correlation analysis using a multi-year dataset for two different seasons. A variety of features have been found to be robust across different datasets and different methods of estimating the correlation, and also consistent with past studies that used in-situ measurements. Areas that consistently show positive correlations are the tropical biomass burning regions for both seasons and the northern midlatitude continental outflow regions in the summer. Among the latter, the area with the highest correlations $(>0.8)$ is the northern Pacific, not just near east Asia, but even close to the west coast of North America. Areas of negative correlations include the high northern latitudes in both seasons, as well as regions like the Sahara and the Middle East.

We evaluated two models' (G-PUCCINI, UKCA) ability to capture the $\mathrm{O}_{3}-\mathrm{CO}$ correlations and found that GPUCCINI has a good skill, especially in summer months, but also has some weaknesses, especially in the winter over the tropics. The UKCA model, whose simulated $\mathrm{O}_{3}$ abundances are not very different to these of the G-PUCCINI model, is able to capture some of the features (e.g. in some remote regions), but in general has correlations that are systematically lower than TES and G-PUCCINI over various regions.

By performing a series of sensitivity experiments, we find that the only individual type of emission which is able to explain the sign of an important correlation pattern by its own, is biomass burning in the tropics. The rest of the features of the geographical distribution remain similar when excluding different individual types of emissions in our model experiments. However, the magnitude of the correlations do change, especially downwind of emission regions, where $\mathrm{O}_{3}$ production is affected by the perturbations that we apply. The analysis also reveals that emissions and chemical processing are most likely not the reason for the UKCA model underestimates of $\mathrm{O}_{3}-\mathrm{CO}$ correlations. We discuss that the discrepances are more likely due to differences in vertical and horizontal mixing.

There is still a lot to be examined and explained about the features of our correlation maps. In particular, more analysis could be performed to understand the influence of the dynamics on the $\mathrm{O}_{3}$-CO relationship. Studying the correlations at higher altitudes would possibly enhance our understanding of the role of STE and convection. It would also be very useful to examine the correlation patterns for other seasons, like Northern Hemisphere spring, when STE is more intense at midlatitudes. Upper tropospheric ozone and $\mathrm{CO}$ 
data from the Aura Microwave Limb Sounder (MLS) could also be used for these purposes. Another interesting implication of our approach would be to study the $\mathrm{O}_{3}-\mathrm{CO}$ correlation in a modeled future atmosphere, taking into account climate change and stratospheric $\mathrm{O}_{3}$ recovery, both of which have the potential to influence tropospheric chemistry.

In general, we have showed that the correlation maps presented here are fairly robust and we believe that they are suitable for use for comparisons in future model evaluations. The observed correlations (Fig. 3a, b) are in principle the most reliable, while the G-PUCCINI correlations from raw model output (Fig. 6c, g) can also provide a straightforward benchmark for comparison with other models (especially since raw model correlations have not been degraded by the observational error). This is especially true for the Northern Hemisphere summer, when performance is even better. Overall, the method presented here could be a useful addition to multi-model validation efforts that will be materialized in the future, providing insight into the models' ability to simulate $\mathrm{O}_{3}$ well for the right reasons. With further work, we may also be able to link discrepances in the $\mathrm{O}_{3}$ - $\mathrm{CO}$ correlation with particular weaknesses in models, something that is not fully allowed by our current level of understanding.

Acknowledgements. We wish to thank NASA's Atmospheric Chemistry Modeling and Analysis Program, NCAS-Climate and NCEO (UK) for supporting this work. We would also like to thank Jennifer Logan and Lin Zhang (Harvard) for the stimulating discussions on this project.

Edited by: M. Kopacz

\section{References}

Aghedo, A. M., Bowman, K. W., Worden, H. M., Kulawik, S. S., Shindell, D. T., Lamarque, J. F., Faluvegi, G., Parrington, M., Jones, D. B. A., and Rast, S.: The vertical distribution of ozone instantaneous radiative forcing from satellite and chemistry climate models, J. Geophys. Res., 116, D01305, doi:10.1029/2010JD014243, 2011.

Ancellet, G., Leclair de Bellevue, J., Mari, C., Nedelec, P., Kukui, A., Borbon, A., and Perros, P.: Effects of regional-scale and convective transports on tropospheric ozone chemistry revealed by aircraft observations during the wet season of the AMMA campaign, Atmos. Chem. Phys., 9, 383-411, doi:10.5194/acp-9-3832009, 2009.

Andreae, M. O., Anderson, B. E., Blake, D. R., Bradshaw, J. D., Collins, J. E., Gregory, G. L., Sachse, G. W., and Shipham, M. C.: Influence of plumes from biomass burning on atmospheric chemistry over the equatorial and tropical South Atlantic during CITE 3, J. Geophys. Res., 99(D6), 12793-12808, 1994.

Beer, R., Glavich, T. A., and Rider, D. M.: Tropospheric emission spectrometer for the Earth Observing System's Aura Satellite, Appl. Opt., 40, 2356-2367, 2001.

Bertschi, I. T. and Jaffe, D. A.: Long-range transport of ozone, carbon monoxide, and aerosols to the NE Pacific troposphere during the summer of 2003: Observations of smoke plumes from Asian boreal fires, J. Geophys. Res., 110(D5), D05303, doi:10.1029/2004JD005135, 2005.

Bian, H. and Prather, M.: Fast-J2: Accurate Simulation of Stratospheric Photolysis in Global Chemical Models, J. Atmos. Chem., 41, 281-296, 2002.

Bowman, K. W., Worden, J., Steck, T., Worden, H. M., Clough, S., and Rodgers, C.: Capturing time and vertical variability of tropospheric ozone: A study using TES nadir retrievals, J. Geophys. Res., 107(D23), 4723, doi:10.1029/2002JD002150, 2002.

Bowman, K. W., Rodgers, C. D., Kulawik, S. S., Worden, J., Sarkissian, E., Osterman, G., Steck, T., Lou, M., Eldering, A., Shephard, M., Worden, H., Lampel, M., Clough, S., Brown, P., Rinsland, C., Gunson, M., and Beer, R.: Tropospheric emission spectrometer: Retrieval method and error analysis, IEEE Trans. Geosci. Remote. Sens., 44, 1297-1307, 2006.

Bowman, K. W., Jones, D. B. A., Logan, J. A., Worden, H., Boersma, F., Chang, R., Kulawik, S., Osterman, G., Hamer, P., and Worden, J.: The zonal structure of tropical $\mathrm{O}_{3}$ and $\mathrm{CO}$ as observed by the Tropospheric Emission Spectrometer in November 2004 - Part 2: Impact of surface emissions on $\mathrm{O}_{3}$ and its precursors, Atmos. Chem. Phys., 9, 3563-3582, doi:10.5194/acp-93563-2009, 2009.

Boxe, C. S., Worden, J. R., Bowman, K. W., Kulawik, S. S., Neu, J. L., Ford, W. C., Osterman, G. B., Herman, R. L., Eldering, A., Tarasick, D. W., Thompson, A. M., Doughty, D. C., Hoffmann, M. R., and Oltmans, S. J.: Validation of northern latitude Tropospheric Emission Spectrometer stare ozone profiles with ARC-IONS sondes during ARCTAS: sensitivity, bias and error analysis, Atmos. Chem. Phys., 10, 9901-9914, doi:10.5194/acp10-9901-2010, 2010.

Buhr, M., Sueper, D., Trainer, M., Goldan, P., Kuster, W., Fehsenfeld, F., Kok, G., Shillawski, R., and Schanot, A.: Trace gas and aerosol measurements using aircraft data from the North Atlantic Regional Experiment (NARE 1993), J. Geophys. Res., 101(D22), 29013-29027, 1996.

Butkovskaya, N., Kukui, A., and Le Bras, G.: $\mathrm{HNO}_{3}$ forming channel of the $\mathrm{HO}_{2}+\mathrm{NO}$ reaction as a function of pressure and temperature in the ranges of 72-600 Torr and 223-323 K, J. Phys. Chem. A, 111, 9047-9053, 2007.

Cárdenas, L. M., Austin, J. F., Burgess, R. A., Clemithsaw, K. C., Dorling, S., Penkett, S. A., and Harrison, R. M.: Correlations between $\mathrm{CO}, \mathrm{NO}_{y}, \mathrm{O}_{3}$ and non-methane hydrocarbons and their relationships with meteorology during winter 1993 on the north Norfolk coast, UK, Atmos. Environ., 32, 3339-3351, 1998.

Chan, C. Y., Chan, L. Y., Lam, K. S., Li, Y. S., Harris, J. M., and Oltmans, S. J.: Effects of Asian air pollution transport and photochemistry on carbon monoxide variability and ozone production in subtropical coastal south China, J. Geophys. Res., 107(D24), 4746, doi:10.1029/2002JD002131, 2002.

Chin, M., Jacob, D. J., Munger, J. W., Parrish, D. D., and Doddridge, B. G.: Relationship of ozone and carbon monoxide over North America, J. Geophys. Res., 99(D7), 14565-14573, 1994.

Collins, J. E., Anderson, B. E., Sachse, G. W., Barrick, J. D. W., Wade, L. O., Burney, L. G., and Hill, G. H.: Atmospheric fine structure during GTE TRACE A: Relationships among ozone, carbon monoxide, and water vapor, J. Geophys. Res., 101(D19), 24307-24316, 1996.

Cooper, O. R., Moody, J. L., Parrish, D. D., Trainer, M., Holloway, J. S., Hubler, G., Fehsenfeld, F. C., and Stohl, A.: Trace gas com- 
position of midlatitude cyclones over the western North Atlantic Ocean: A seasonal comparison of O-3 and CO, J. Geophys. Res., 107, 4057, doi:10.1029/2001JD000902, 2002a.

Cooper, O. R., Moody, J. L., Parrish, D. D., Trainer, M., Ryerson, T. B., Holloway, J. S., Hubler, G., Fehsenfeld, F. C., and Evans, M. .: Trace gas composition of midlatitude cyclones over the western North Atlantic Ocean: A conceptual model, J. Geophys. Res., 107, 4056, doi:10.1029/2001JD000901, 2002b.

Daum, P. H., Kleinman, L. I., Newman, L., Luke, W. T., WeinsteinLloyd, J., Berkowitz, C. M., and Busness, K. M.: Chemical and physical properties of plumes of anthropogenic pollutants transported over the North Atlantic during the North Atlantic Regional Experiment, J. Geophys. Res., 101(D22), 29029-29042, 1996.

Dentener, F., Drevet, J., Lamarque, J. F., Bey, I., Eickhout, B., Fiore, A. M., Hauglustaine, D., Horowitz, L. W., Krol, M., Kulshrestha, U. C., Lawrence, M., Galy-Lacaux, C., Rast, S., Shindell, D., Stevenson, D., van Noije, T., Atherton, C., Bell, N., Bergman, D., Butler, T., Cofala, J., Collins, B., Doherty, R., Ellingsen, K., Galloway, J., Gauss, M., Montanaro, V., Müller, J.-F., Pitari, G., Rodriguez, J., Sanderson, M., Solmon, F., Strahan, S., Schultz, M., Sudo, K., Szopa, S., and Wild, O.: Nitrogen and sulfur deposition on regional and global scales: A multimodel evaluation, Global Biogeochem. Cy., 20, GB4003, doi:10.1029/2005GB002672, 2006.

Ding, A., Wang, T., Xue, L., Gao, J., Stohl, A., Lei, H., Jin, D., Ren, Y., Wang, X., Wei, X., Qi, Y., Liu, J., and Zhang, X.: Transport of north China air pollution by midlatitude cyclones: Case study of aircraft measurements in summer 2007, J. Geophys. Res., 114, D08304, doi:10.1029/2008JD011023, 2009.

Fiore, A. M., Dentener, F. J., Wild, O., Cuvelier, C., Schultz, M. G., Hess, P., Textor, C., Schulz, M., Doherty, R. M., Horowitz, L. W., MacKenzie, I. A., Sanderson, M. G., Shindell, D. T., Stevenson, D. S., Szopa, S., Van Dingenen, R., Zeng, G., Atherton, C., Bergmann, D., Bey, I., Carmichael, G., Collins, W. J., Duncan, B. N., Faluvegi, G., Folberth, G., Gauss, M., Gong, S., Hauglustaine, D., Holloway, T., Isaksen, I. S. A., Jacob, D. J., Jonson, J. E., Kaminski, J. W., Keating, T. J., Lupu, A., Marmer, E., Montanaro, V., Park, R. J., Pitari, G., Pringle, K. J., Pyle, J. A., Schroeder, S., Vivanco, M. G., Wind, P., Wojcik, G., Wu, S., and Zuber, A.: Multimodel estimates of intercontinental sourcereceptor relationships for ozone pollution, J. Geophys. Res., 114, D04301, doi:10.1029/2008JD010816, 2009.

Fischer, H., Kormann, R., Klüpfel, T., Gurk, Ch., Königstedt, R., Parchatka, U., Mühle, J., Rhee, T. S., Brenninkmeijer, C. A. M., Bonasoni, P., and Stohl, A.: Ozone production and trace gas correlations during the June 2000 MINATROC intensive measurement campaign at Mt. Cimone, Atmos. Chem. Phys., 3, 725-738, doi:10.5194/acp-3-725-2003, 2003.

Gao, J., Wang, T., Ding, A., and Liu, C.: Observational study of ozone and carbon monoxide at the summit of mount Tai $(1534 \mathrm{~m}$ a.s.1.) in central-eastern China, Atmos. Environ., 39, 47794791, 2005.

Gery, M. W., Whitten, G. Z., Killus, J. P., and Dodge, M. C.: A photochemical kinetics mechanism for urban and regional scale computer modeling, J. Geophys. Res., 94, 12925-12956, 1989.

Guenther, A., Hewitt, C. N., Erickson, D., Fall, R., Geron, C., Graedel, T., Harley, P., Klinger, L., Lerdau, M., McKay, W. A., Pierce, T., Scoles, B., Steinbrecher, R., Tallaam- raju, R., Taylor, J., and Zimmerman, P.: A global model of natural volatile organic compound emissions, J. Geophys. Res., 100, 8873-8892, http://www.agu.org/pubs/crossref/1995... /94JD02950.shtml, 1995.

Guenther, A., Karl, T., Harley, P., Wiedinmyer, C., Palmer, P. I., and Geron, C.: Estimates of global terrestrial isoprene emissions using MEGAN (Model of Emissions of Gases and Aerosols from Nature), Atmos. Chem. Phys., 6, 3181-3210, doi:10.5194/acp-63181-2006, 2006.

Hanson, D. and Mauersberger, K.: Laboratory studies of the nitric acid tridydrate: Implications for the south polar stratosphere, Geophys. Res. Lett., 15, 855—858, 1988.

Harris, J. M., Oltmans, S. J., Dlugokencky, E. J., Novelli, P. C., Johnson, B. J., and Mettford, T.: An investigation into the source of the springtime tropospheric ozone maximum at Mauna Loa Observatory, J. Geophys. Res., 25, 1895-1898, 1998.

Harris, J. M., Dlugokencky, E. J., Oltmans, S. J., Tans, P. P., Conway, T. J., Novelli, P. C., Thoning, K. W., and Kahl, J. D. W.: An interpretation of trace gas correlations during Barrow, Alaska, winter dark periods, 1986-1997, J. Geophys. Res., 105(D13), 17267-17278, 2000.

Hegarty, J., Mao, H., and Talbot, R.: Synoptic influences on springtime tropospheric $\mathrm{O}_{3}$ and $\mathrm{CO}$ over the North American export region observed by TES, Atmos. Chem. Phys., 9, 3755-3776, doi:10.5194/acp-9-3755-2009, 2009.

Hegarty, J., Mao, H., and Talbot, R.: Winter- and summertime continental influences on tropospheric $\mathrm{O}_{3}$ and $\mathrm{CO}$ observed by TES over the western North Atlantic Ocean, Atmos. Chem. Phys., 10, 3723-3741, doi:10.5194/acp-10-3723-2010, 2010.

Henne, S., Klausen, J., Junkermann, W., Kariuki, J. M., Aseyo, J. O., and Buchmann, B.: Representativeness and climatology of carbon monoxide and ozone at the global GAW station Mt. Kenya in equatorial Africa, Atmos. Chem. Phys., 8, 3119-3139, doi:10.5194/acp-8-3119-2008, 2008.

Honrath, R. E., Owen, R. C., Val Martin, M., Reid, J. S., Lapina, K., Fialho, P., Dziobak, M. P., Kleissl, J., and Westphal, D. L.: Regional and hemispheric impacts of anthropogenic and biomass burning emissions on summertime $\mathrm{CO}$ and $\mathrm{O}_{3}$ in the North Atlantic lower free troposphere, J. Geophys. Res., 109(D24), D24310, doi:10.1029/2004JD005147, 2004.

Houweling, S., Dentener, F., and Lelieveld, J.: The impact of nonmethane hydrocarbon compounds on tropospheric photochemistry, J. Geophys. Res., 103, 10673-10696, 1998.

Hoyle, C. R., Marécal, V., Russo, M. R., Arteta, J., Chemel, C., Chipperfield, M. P., D’Amato, F., Dessens, O., Feng, W., Harris, N. R. P., Hosking, J. S., Morgenstern, O., Peter, T., Pyle, J. A., Reddmann, T., Richards, N. A. D., Telford, P. J., Tian, W., Viciani, S., Wild, O., Yang, X., and Zeng, G.: Tropical deep convection and its impact on composition in global and mesoscale models - Part 2: Tracer transport, Atmos. Chem. Phys. Discuss., 10, 20355-20404, doi:10.5194/acpd-10-20355-2010, 2010.

Hsu, J., Prather, M. J., Wild, O., Sundet, J. K., Isaksen, I. S. A., Browell, E. V., Avery, M. A., and Sachse, G. W.: Are the TRACE-P measurements representative of the western Pacific during March 2001?, J. Geophys. Res., 109(D2), D02314, doi:10.1029/2003JD004002, 2004.

Huntrieser, H., Heland, J., Schlager, H., Forster, C., Stohl, A., Aufmhoff, H., Arnold, F., Scheel, H. E., Campana, M., Gilge, S., Eixmann, R., and Cooper, O.: Intercontinental air pollu- 
tion transport from North America to Europe: Experimental evidence from airborne measurements and surface observations, J. Geophys. Res., 110(D1), D01305, doi:10.1029/2004JD005045, 2005.

Jaffe, D., Yurganov, L., Pullman, E., Reuter, J., Mahura, A., and Novelli, P.: Measurements of $\mathrm{CO}$ and $\mathrm{O}_{3}$ at Shemya, Alaska, J. Geophys. Res., 103(D1), 1493-1502, 1998.

Jaffe, D. A., Honrath, R. E. snd Zhang, L., Akimoto, H., Shimizu, A., Mukai, H., Murano, K., Hatakeyama, S., and Merrill, J.: Measurements of $\mathrm{NO}, \mathrm{NO}_{y}, \mathrm{CO}$ and $\mathrm{O}_{3}$ and estimation of the ozone production rate at Oki Island, Japan, during PEM-West, J. Geophys. Res., 101(D1), 2037-2048, 1996.

Jones, D. B. A., Bowman, K. W., Palmer, P. I., Worden, J. R., Jacob, D. J., Hoffmann, R. N., Bey, I., and Yantosca, R. M.: Potential of observations from the Tropospheric Emission Spectrometer to constrain continental sources of carbon monoxide, J. Geophys. Res., 108(D24), 4789, doi:10.1029/2003JD003702, 2003.

Kajii, Y., Someno, K., Tanimoto, H., Hirokawa, J., Akimoto, H., Katsuno, T., and Kawar, J.: Evidence for the seasonal variation of photochemical activity of tropospheric ozone: Continuous observation of ozone and $\mathrm{CO}$ at Happo, Japan, J. Geophys. Res., 25, 3505-3508, 1998.

Kalnay, E., Kanamitsu, M., Kistler, R., Collins, W., Deaven, D., Gandin, L., Iredell, M., Saha, S., White, G., Woollen, J., Zhu, Y., Leetmaa, A., Reynolds, B., Chelliah, M., Ebisuzaki, W., Higgins, W., Janowiak, J., Mo, K., Ropelewski, C., Wang, J., Jenne, R., and Joseph, D.: The NCEP/NCAR 40-year reanalysis project, B. Am. Meteorol. Soc., 77, 437-471, doi:10.1175/15200477(1996)077;0437:TNYRP;2.0.CO;2, 1996.

Kato, S., Kajii, Y., Itokazu, R., Hirokawa, J., Koda, S., and Kinjo, Y.: Transport of atmospheric carbon monoxide, ozone, and hydrocarbons from Chinese coast to Okinawa island in the Western Pacific during winter, Atmos. Environ., 38, 2975-2981, doi:10.1016/j.atmosenv.2004.02.049, 2004.

Lamarque, J.-F., Bond, T. C., Eyring, V., Granier, C., Heil, A., Klimont, Z., Lee, D., Liousse, C., Mieville, A., Owen, B., Schultz, M. G., Shindell, D., Smith, S. J., Stehfest, E., Van Aardenne, J., Cooper, O. R., Kainuma, M., Mahowald, N., McConnell, J. R., Naik, V., Riahi, K., and van Vuuren, D. P.: Historical (1850-2000) gridded anthropogenic and biomass burning emissions of reactive gases and aerosols: methodology and application, Atmos. Chem. Phys., 10, 7017-7039, doi:10.5194/acp10-7017-2010, 2010.

Law, K. S. and Pyle, J. A.: Modeling trace gas budgets in the troposphere 1. Ozone and odd nitrogen, J. Geophys. Res., 98, 1837718400, 1993.

Law, K. S., Plantevin, P. H., Shallcross, D. E., Rogers, H. J., Pyle, J. A., Grouhel, C., Thouret, V., and Marenco, A.: Evaluation of modeled $\mathrm{O}_{3}$ using Measurement of Ozone by Airbus In-Service Aircraft (MOZAIC) data, J. Geophys. Res., 103, 25721-25737, 1998.

Lelieveld, J. and Dentener, F.: What controls tropospheric ozone?, J. Geophys. Res., 105, 3531-3551, 2000.

Li, Q. B., Jacob, D. J., Bey, I., Palmer, P. I., Duncan, B. N., Field, B. D., Martin, R. V., Fiore, A. M., Yantosca, R. M., Parrish, D. D., Simmonds, P. G., and Oltmans, S. J.: Transatlantic transport of pollution and its effects on surface ozone in Europe and North America, J. Geophys. Res., 107(D13), 4166, doi:10.1029/2001JD001422, 2002.
Liu, J., Logan, J. A., Jones, D. B. A., Livesey, N. J., Megretskaia, I. A., Carouge, C. C., and Nedelec, P.: Analysis of CO in the tropical troposphere using Aura satellite data and the GEOS-Chem model: insights into transport characteristics of the GEOS meteorological products, Atmos. Chem. Phys. Discuss., 10, 1963119695, doi:10.5194/acpd-10-19631-2010, 2010.

Liu, J. J., Jones, D. B. A., Worden, J. R., Noone, D., Parrington, M., and Kar, J.: Analysis of the summertime buildup of tropospheric ozone abundances over the Middle East and North Africa as observed by the Tropospheric Emission Spectrometer instrument, J. Geophys. Res., 114, D05304, doi:10.1029/2008JD010993, 2009.

Logan, J. A., Prather, M. J., Wolfsy, S. C., and McElroy, M. B.: Tropospheric chemistry: A global perspective, J. Geophys. Res., 86, 7210-7254, 1981.

Lopez, J. P., Luo, M., Christensen, L. E., Loewenstein, M., Jost, H., Webster, C. R., and Osterman, G.: TES carbon monoxide validation during two AVE campaigns using the Argus and ALIAS instruments on NASA's WB-57F, J. Geophys. Res., 113, D16S47, doi:10.1029/2007JD008811, 2008.

Luo, M., Rinsland, C., Fisher, B., Sachse, G., Diskin, G., Logan, J., Worden, H., Kulawik, S., Osterman, G., Eldering, A., Herman, R., and Shephard, M.: TES carbon monoxide validation with DACOM aircraft measurements during INTEX-B 2006b, J. Geophys. Res., 112, D24S48, doi:10.1029/2007JD008803, 2007.

Mao, H. and Talbot, R.: $\mathrm{O}_{3}$ and $\mathrm{CO}$ in New England: Temporal variations and relationships, J. Geophys. Res., 109, D21304, doi:10.1029/2004JD004913, 2004.

Mauzerall, D. L., Narita, D., Akimoto, H., Horowitz, L., Walters, S., Hauglustaine, D. A., and Brasseur, G.: Seasonal characteristics of tropospheric ozone production and mixing ratios over East Asia: A global three-dimensional chemical transport model analysis, J. Geophys. Res., 105(D14), 17895-17910, 2000.

Morgenstern, O., Braesicke, P., O'Connor, F. M., Bushell, A. C., Johnson, C. E., Osprey, S. M., and Pyle, J. A.: Evaluation of the new UKCA climate-composition model - Part 1: The stratosphere, Geosci. Model Dev., 2, 43-57, doi:10.5194/gmd-2-432009, 2009.

Naja, M., Lal, S., and Chand, D.: Diurnal and seasonal variabilities in surface ozone at a high altitude site Mt Abu (24.6 degrees N, 72.7 degrees E, $1680 \mathrm{~m}$ asl) in India, Atmos. Environ., 37, 42054215, doi:10.1016/S1352-2310(03)00565-X, 2003.

Nassar, R., Logan, J. A., Worden, H. M., Megretskaia, I. A., Bowman, K. W., Osterman, G. B., Thompson, A. M., Tarasick, D. W., Austin, S., Claude, H., Dubey, M. K., Hocking, W. K., Johnson, B. J., Joseph, E., Merrill, J., Morris, G. A., Newchurch, M., Oltmans, S. J., Posny, F., Schmidlin, F. J., Vomel, H., Whiteman, D. N., and Witte, J. C.: Validation of Tropospheric Emission Spectrometer (TES) nadir ozone profiles using ozonesonde measurements, J. Geophys. Res., 113, D15S17, doi:10.1029/2007JD008819, 2008.

Nowak, J. B., Parrish, D. D., Neuman, J. A., Holloway, J. S., Cooper, O. R., Ryerson, T. B., Nicks, D. K., Flocke, F., Roberts, J. M., Atlas, E., de Gouw, J. A., Donnelly, S., Dunlea, E., Hubler, G., Huey, L., Schauffler, S., Tanner, D., Warneke, C., and Fehsenfeld, F.: Gas-phase chemical characteristics of Asian emission plumes observed during ITCT $2 \mathrm{~K} 2$ over the eastern North Pacific Ocean, J. Geophys. Res., 109(D23), D23S19, doi:10.1029/2003JD004488, 2004.

O’Connor, F. M., Johnson, C., Morgenstern, O., Young, P., Collins, 
W., and Pyle, J.: Evaluation of the new UKCA climatecomposition model. Part 2: The Troposphere, Geosci. Model Dev. Discuss., in preparation, 2011.

Osterman, G. B., Kulawik, S. S., Worden, H. M., Richards, N. A. D., Fisher, B. M., Eldering, A., Shephard, M. W., Froidevaux, L., Labow, G., Luo, M., Herman, R. L., Bowman, K. W., and Thompson, A. M.: Validation of Tropospheric Emission Spectrometer (TES) measurements of the total, stratospheric, and tropospheric column abundance of ozone, J. Geophys. Res., 113, D15S16, doi:10.1029/2007JD008801, 2008.

Parrington, M., Jones, D. B. A., Bowman, K. W., Horowitz, L. W., Thompson, A. M., Tarasick, D. W., and Witte, J. C.: Estimating the summertime tropospheric ozone distribution over North America through assimilation of observations from the Tropospheric Emission Spectrometer, J. Geophys. Res., 113, D18307, doi:10.1029/2007JD009341, 2008.

Parrish, D. D., Holloway, J. S., Trainer, M., Murphy, P. C., Forbes, G. L., and Fehsenfeld, F. C.: Export of North American Ozone Pollution to the North Atlantic Ocean, Science, 259, 1436-1439, 1993.

Parrish, D. D., Trainer, M., Holloway, J. S., Yee, J. E., Warshawasky, M. S., and Fehsenfeld, F. C.: Relationships between ozone and carbon monoxide at surface sites in the North Atlantic region, J. Geophys. Res., 103(D11), 13357-13376, 1998.

Pochanart, P., Hirokawa, J., Yoshizumi, K., and Akimoto, H.: Influence of regional-scale anthropogenic activity in northeast Asia on seasonal variations of surface ozone and carbon monoxide observed at Oki, Japan, J. Geophys. Res., 104(D3), 3621-3631, 1999.

Prather, M. J.: Numerical Advection by Conservation of SecondOrder Moments, J. Geophys. Res., 91, 6671-6681, 1986.

Price, C. and Rind, D.: Modeling global lightning distributions in a General Circulation Model, Mon. Weather Rev., 122, 19301939, 1994.

Price, C., Penner, J., and Prather, M.: NOx from lightning, 1, Global distribution based on lightning physics, J. Geophys. Res., 102, 5929-5941, 1997.

Priestley, A.: A quasi-conservative version of the semilagrangian advection scheme, Mon. Weather Rev., 121, p. 621, 1993.

Randerson, J. T., van der Werf, G. R., Giglio, L., Collatz, G. J., and Kasibhatla, P. S.: Global Fire Emissions Database, Version 2 (GFEDv2.1), Tech. rep., Data set. Available on-line [http://daac.ornl.gov/] from Oak Ridge National Laboratory Distributed Active Archive Center, Oak Ridge, Tennessee, USA, doi:10.3334/ORNLDAAC/849, 2007.

Rayner, N. A., Parker, D. E., Horton, E. B., Folland, C. K., Alexander, L. V., Rowell, D. P., Kent, E. C., and Kaplan, A.: Global analyses of sea surface temperature, sea ice, and night marine air temperature since the late nineteenth century, J. Geophys. Res., 108(D14), 4407, doi:10.1029/2002JD002670, 2003.

Real, E., Law, K. S., Schlager, H., Roiger, A., Huntrieser, H., Methven, J., Cain, M., Holloway, J., Neuman, J. A., Ryerson, T., Flocke, F., de Gouw, J., Atlas, E., Donnelly, S., and Parrish, D.: Lagrangian analysis of low altitude anthropogenic plume processing across the North Atlantic, Atmos. Chem. Phys., 8, 77377754, doi:10.5194/acp-8-7737-2008, 2008.

Richards, N. A. D., Osterman, G. B., Browell, E. V., Hair, J. W., Avery, M., and Li, Q.: Validation of Tropospheric Emission Spectrometer ozone profiles with aircraft observations during the
Intercontinental Chemical Transport Experiment-B, J. Geophys. Res., 113, D16S29, doi:10.1029/2007JD008815, 2008.

Rodgers, C. D.: Inverse Methods for Atmospheric Sounding: Theory and Practice, World Sci., Hackensack, NJ, 2000.

Sander, S. P., Friedl, R. R., Golden, D. M., and et al.: Chemical kinetics and photochemical data for use in stratospheric modeling, Eval. 13, Tech. rep., JPL Publ., 2000.

Sanderson, M. G., Dentener, F. J., Fiore, A. M., Cuvelier, C., Keating, T. J., Zuber, A., Atherton, C. S., Bergmann, D. J., Diehl, T., Doherty, R. M., Duncan, B. N., Hess, P., Horowitz, L. W., Jacob, D. J., Jonson, J. E., Kaminski, J. W., Lupu, A., MacKenzie, I. A., Mancini, E., Marmer, E., Park, R., Pitari, G., Prather, M. J., Pringle, K. J., Schroeder, S., Schultz, M. G., Shindell, D. T., Szopa, S., Wild, O., and Wind, P.: A multi-model study of the hemispheric transport and deposition of oxidised nitrogen, Geophys. Res. Lett., 35, L17815, doi:10.1029/2008GL035389, 2008.

Sanhueza, E., Crutzen, P. J., and Fernández, E.: Production of boundary layer ozone from tropical American Savannah biomass burning emissions, Atmos. Environ., 33, 4969-4975, 1999.

Schmidt, G. A., Ruedy, R., Hansen, J. E., Aleinov, I., Bell, N., Bauer, M., Bauer, S., Cairns, B., Canuto, V., Cheng, Y., Del Genio, A., Faluvegi, G., Friend, A. D., Hall, T. M., Hu, Y. Y., Kelley, M., Kiang, N. Y., Koch, D., Lacis, A. A., Lerner, J., Lo, K. K., Miller, R. L., Nazarenko, L., Oinas, V., Perlwitz, J., Perlwitz, J., Rind, D., Romanou, A., Russell, G. L., Sato, M., Shindell, D. T., Stone, P. H., Sun, S., Tausnev, N., Thresher, D., and Yao, M. S.: Present-day atmospheric simulations using GISS ModelE: Comparison to in situ, satellite, and reanalysis data, J. Climate, 19, 153-192, 2006.

Shim, C., Li, Q., Luo, M., Kulawik, S., Worden, H., Worden, J., Eldering, A., Diskin, G., Sachse, G., Weinheimer, A., Knapp, D., Montzca, D., and Campos, T.: Satellite observations of Mexico City pollution outflow from the Tropospheric Emissions Spectrometer (TES), Atmos. Environ., 43, 1540-1547, doi:10.1016/j.atmosenv.2008.11.026, 2009.

Shindell, D. T., Faluvegi, G., Stevenson, D. S., Krol, M. C., Emmons, L. K., Lamarque, J.-F., Pétron, G., Dentener, F. J., Ellingsne, K., Schultz, M. G., Wild, O., Amann, M., Atherton, C. S., Bergmann, D. J., Bey, I., Butler, T., Cofala, J., Collins, W. J., Derwent, R. G., Doherty, R. M., Drevet, J., Eskes, H. J., Fiore, A. M., Gauss, M., Hauglustaine, D. A., Horowitz, L. W., Isaksen, I. S. A., Lawrence, M. G., Montanaro, V., Müller, J.-F., Pitari, G., Prather, M. J., Pyle, J. A., Rast, S., Rodriguez, J. M., Sanderson, M. G., Savage, N. H., Strahan, S. E., Sudo, K., Szopa, S., Unger, N., van Noije, T. P. C., and Zeng, G.: Multimodel simulations of carbon monoxide: Comparison with observations and projected near-future changes, J. Geophys. Res., 111, D19306, doi:10.1029/2006JD007100, 2006a.

Shindell, D. T., Faluvegi, G., Unger, N., Aguilar, E., Schmidt, G. A., Koch, D. M., Bauer, S. E., and Miller, R. L.: Simulations of preindustrial, present-day, and 2100 conditions in the NASA GISS composition and climate model G-PUCCINI, Atmos. Chem. Phys., 6, 4427-4459, doi:10.5194/acp-6-4427-2006, 2006b.

Staniforth, A., White, A., Wood, N., Thuburn, J., Zaerroukat, M., Cordero, E., and Davies, T.: Joy of UM6.1-Model Formulation, Tech. rep., United Kingdom Meteorological Office (UKMO), 2005. 
Stevenson, D. S., Dentener, F. J., Schultz, M. G., Ellingsen, K., van Noije, T. P. C., Wild, O., Zeng, G., Amann, M., Atherton, M., Bell, N., Bergmann, D. J., Bey, I., Bulter, T., Cofala, J., Collins, W. J., Derwent, R. G., Doherty, R. M., Drevet, J., Eskes, H. J., Fiore, A. M., Gauss, M., Hauglustaine, D. A., Horowitz, L. W., Isaksen, I. S. A., Krol, M. C., Lamarque, J.-F., Lawrence, M. G., Montanaro, V., Müller, J. F., Pitari, G., Prather, M. J., Pyle, J. A., Rast, S., Rodriguez, J. M., Sanderson, M. G., Savage, N. H., Shindell, D. T., Strahan, S. E., Sudo, K., and Szopa, S.: Multimodel ensemble simulations of present-day and near-future tropospheric ozone, J. Geophys. Res., 111, D08301, doi:10.1029/2005JD006338, 2006.

Suthawaree, J., Kato, S., Takami, A., Kadena, H., Toguchi, M., Yogi, K., Hatakeyama, S., and Kajii, Y.: Observation of ozone and carbon monoxide at Cape Hedo, Japan: Seasonal variation and influence of long-range transport, Atmos. Environ., 42, 2971-2981, doi:10.1016/j.atmosenv.2007.12.053, 2008.

Swartzendruber, P. C., Chand, D., Jaffe, D. A., Smith, J., Reidmiller, D., Gratz, L., Keeler, J., Strode, S., Jaegle, L., and Talbot, R.: Vertical distribution of mercury, CO, ozone, and aerosol scattering coefficient in the Pacific Northwest during the spring 2006 INTEX-B campaign, J. Geophys. Res., 113(D10), D10305, doi:10.1029/2007JD009579, 2008.

Takegawa, N., Kondo, Y., Ko, M., Koike, M., Kita, K., Blake, D. R., $\mathrm{Hu}$, W., Scott, C., Kawakami, S., Miyazaki, Y., Russell-Smith, J., and Ogawa, T.: Photochemical production of $\mathrm{O}_{3}$ in biomass burning plumes in the boundary layer over northern Australia, Geophys. Res. Lett., 30, 1500, doi:10.1029/2003GL017017, 2003.

Tanimoto, H., Matsumoto, K., and Uematsu, M.: Ozone-CO Correlations in Siberian Wildfire Plumes Observed at Rishiri Island, SOLA, 4, 065-068, 2008.

Telford, P. J., Braesicke, P., Morgenstern, O., and Pyle, J. A.: Technical Note: Description and assessment of a nudged version of the new dynamics Unified Model, Atmos. Chem. Phys., 8, 17011712, doi:10.5194/acp-8-1701-2008, 2008.

Telford, P. J., Lathière, J., Abraham, N. L., Archibald, A. T., Braesicke, P., Johnson, C. E., Morgenstern, O., O’Connor, F. M., Pike, R. C., Wild, O., Young, P. J., Beerling, D. J., Hewitt, C. N., and Pyle, J.: Effects of climate-induced changes in isoprene emissions after the eruption of Mount Pinatubo, Atmos. Chem. Phys., 10, 7117-7125, doi:10.5194/acp-10-7117-2010, 2010.

Tsutsumi, Y. and Matsueda, H.: Relationship of ozone and CO at the summit of Mt. Fuji (35.35 degrees N, 138.73 degrees E, 3776 $\mathrm{m}$ above sea level) in summer 1997, Atmos. Environ., 34, 553$561,2000$.

Voulgarakis, A., Savage, N. H., Wild, O., Carver, G. D., Clemitshaw, K. C., and Pyle, J. A.: Upgrading photolysis in the pTOMCAT CTM: model evaluation and assessment of the role of clouds, Geosci. Model Dev., 2, 59-72, doi:10.5194/gmd-2-592009, 2009a.

Voulgarakis, A., Wild, O., Savage, N. H., Carver, G. D., and Pyle, J. A.: Clouds, photolysis and regional tropospheric ozone budgets, Atmos. Chem. Phys., 9, 8235-8246, doi:10.5194/acp-9-82352009, 2009b.
Wang, T., Wong, H. L. A., Tang, J., Ding, A., Wu, W. S., and Zhang, X. C.: On the origin of surface ozone and reactive nitrogen observed at a remote mountain site in the northeastern QinghaiTibetan Plateau, western China, J. Geophys. Res., 111, D08303, doi:10.1029/2005JD006527, 2006.

Wang, T. J., Lam, K. S., Tsang, C. W., and Kot, S. C.: On the variability and correlation of surface ozone and carbon monoxide observed in Hong Kong using trajectory and regression analyses, Adv. Atmos. Sci., 21, 141-152, 2004.

Wang, Y., McElroy, M. B., Munger, J. W., Hao, J., Ma, H., Nielsen, C. P., and Chen, Y.: Variations of $\mathrm{O}_{3}$ and $\mathrm{CO}$ in summertime at a rural site near Beijing, Atmos. Chem. Phys., 8, 6355-6363, doi:10.5194/acp-8-6355-2008, 2008.

Wild, O., Zhu, X., and Prather, M. J.: Fast-J: Accurate simulation of in- and below-cloud photolysis in Global Chemical Models, J. Atmos. Chem., 37, 245-282, 2000.

Worden, H. M., Logan, J. A., Worden, J. R., Beer, R., Bowman, K., Clough, S. A., Eldering, A., Fisher, B. M., Gunson, M. R., Herman, R. L., Kulawik, S. S., Lampel, M. C., Luo, M., Megretskaia, I. A., Osterman, G. B., and Shepard, M. W.: Comparisons of Tropospheric Emission Spectrometer (TES) ozone profiles to ozonesondes: Methods and initial results, J. Geophys. Res., 112, D03309, doi:10.1029/2006JD007258, 2007.

Worden, J., Jones, D. B. A., Liu, J., Parrington, M., Bowman, K., Stajner, I., Beer, R., Jiang, J., Thouret, V., Kulawik, S., Li, J. L. F., Verma, S., and Worden, H.: Observed vertical distribution of tropospheric ozone during the Asian summertime monsoon, J. Geophys. Res., 114, D13304, doi:10.1029/2008JD010560, 2009.

Zahn, A., Brenninkmeijer, C. A. M., Maiss, M., Scharffe, D. H., Crutzen, P. J., Hermann, M., Heintzenberg, J., Wiedensohler, A., Gusten, H., Heinrich, G., Fischer, H., Cuijpers, J. W. M., and van Velthoven, P. F. J.: Identification of extratropical twoway troposphere-stratosphere mixing based on CARIBIC measurements of O-3, CO, and ultrafine particles, J. Geophys. Res., 105(D1), 1527-1535, 2000.

Zhang, L., Jacob, D. J., Bowman, K. W., Logan, J. A., Turquety, S., Hudman, R. C., Li, Q., Beer, R., Worden, H. M., Rinsland, C. P., Kulawik, S. S., Lampel, M. C., Shephard, M. W., Fisher, B. M., Eldering, A., and Avery, M. A.: OzoneCO correlations determined by the TES satellite instrument in continental outflow regions, Geophys. Res. Lett., 33, L18804, doi:10.1029/2006GL026399, 2006.

Zhang, L., Jacob, D. J., Boersma, K. F., Jaffe, D. A., Olson, J. R., Bowman, K. W., Worden, J. R., Thompson, A. M., Avery, M. A., Cohen, R. C., Dibb, J. E., Flock, F. M., Fuelberg, H. E., Huey, L. G., McMillan, W. W., Singh, H. B., and Weinheimer, A. J.: Transpacific transport of ozone pollution and the effect of recent Asian emission increases on air quality in North America: an integrated analysis using satellite, aircraft, ozonesonde, and surface observations, Atmos. Chem. Phys., 8, 6117-6136, doi:10.5194/acp-8-6117-2008, 2008. 